\title{
Late surge glacial conditions on Bakaninbreen, Svalbard, and implications for surge termination
}

\author{
A. M. Smith, ${ }^{1}$ T. Murray, ${ }^{2}$ B. M. Davison, ${ }^{3}$ A. F. Clough, ${ }^{4}$ J. Woodward, ${ }^{2,5}$ \\ and H. Jiskoot ${ }^{2,6}$ \\ Received 1 December 2000; revised 17 December 2001; accepted 22 December 2001; published 6 August 2002.
}

[1] Bakaninbreen is a polythermal glacier in southern Spitsbergen, Svalbard, that last surged between 1985 and 1995. Seismic reflection data were acquired during early quiescence in spring 1998, just upstream of the surge front. The results were combined with complementary ground-penetrating radar data to investigate the glacial structure and basal conditions. We find no difference between the ice thickness values determined from the seismic and radar methods, suggesting that any layer of basal ice cannot be greater than $\sim 5 \mathrm{~m}$ thick. Interpretation of the amplitude of the seismic reflections indicates the presence of permafrost close to the glacier base. A thin layer of thawed deforming sediment separates the glacier from this underlying permafrost. In an area just upstream of the surge front the permafrost becomes discontinuous and may even be absent, the ice being underlain by $10-15 \mathrm{~m}$ of thawed sediments overlying deeper bedrock. Highpressure water is believed to have been required to maintain the propagation of the surge, and this area of thawed sediment is interpreted as a route for that water to escape from the basal system. When the surge front passed over this thawed bed, the escaping water reduced the pressure in the subglacial hydraulic system, initiating the termination of the surge. Surge termination was therefore primarily controlled by the presurge permafrost distribution beneath the glacier, rather than any feature of the surge itself. This termination mechanism is probably limited to surges in polythermal glaciers, but the techniques used may have wider glaciological applications. INDEX TERMS: 0935 Exploration Geophysics: Seismic methods (3025); 1823 Hydrology: Frozen ground; 1827 Hydrology: Glaciology (1863); 9315 Information Related to Geographic Region: Arctic region; KEYWORDS: Seismic, GPR, glacier, surge, permafrost, Arctic

\section{Introduction}

\subsection{Glacier Surging}

[2] Surge-type glaciers show a remarkably bimodal dynamic behavior. An internally triggered flow instability [Meier and Post, 1969] results in a recurring sequence of slow and fast ice flow in which relatively long quiescent periods are separated by surges. The quiescent periods (20to $>200$-year duration) are characterized by slow ice flow and a gradual buildup of ice in the upstream regions. During a surge, ice flow can increase by more than 2 orders of magnitude for a relatively short period ( 1 to $>10$ years) and ice from the upstream reservoir is transported rapidly down-

\footnotetext{
${ }^{1}$ Physical Sciences Division, British Antarctic Survey, Natural Environmental Research Council, Cambridge, UK.

${ }^{2}$ School of Geography, University of Leeds, Leeds, UK.

${ }^{3}$ Institute of Environmental and Biological Sciences, Lancaster University, Lancaster, UK.

${ }^{4}$ School of Earth Sciences, University of Leeds, Leeds, UK.

${ }^{5}$ Now at Department of Geography and Earth Sciences, Brunel University, Uxbridge, UK.

${ }^{6}$ Now at Department of Geography, University of Calgary, Calgary, Alberta, Canada.

Copyright 2002 by the American Geophysical Union. 0148-0227/02/2001JB000475\$09.00
}

stream. Fast ice flow during the surge is believed to result from increased basal motion associated with high water pressures and decoupling from the bed [e.g., Clarke, 1987], though there is evidence for different mechanisms by which this is achieved. Sliding over a reorganized basal drainage system [e.g., Kamb et al., 1985; Kamb, 1987; Björnsson, 1998] and deformation of weak, water-saturated sediments [e.g., Clarke et al., 1984] have both been proposed. Surging occurs in both polythermal and temperate glaciers and different mechanisms or combinations of mechanisms may be dominant factors in different regimes. Surges in polythermal, high Arctic glaciers (e.g., in the Svalbard Archipelago) are characterized by slow speeds, prolonged termination, and long quiescence. In contrast, surges in Alaska and Iceland, for example, where glaciers are typically temperate, are much faster, terminate rapidly and occur more frequently [e.g., Dowdeswell et al., 1991]. There is also evidence for similarities between the different surge types, the thickness of the deforming sediment layer beneath a surge being one example [Fuller and Murray, 2000; Murray et al., 2000]. Whatever the mechanisms involved, it is generally accepted that basal conditions are fundamental to glacier surging. However, a lack of observations, particularly during the surge itself, still limits the understanding of surge processes. 


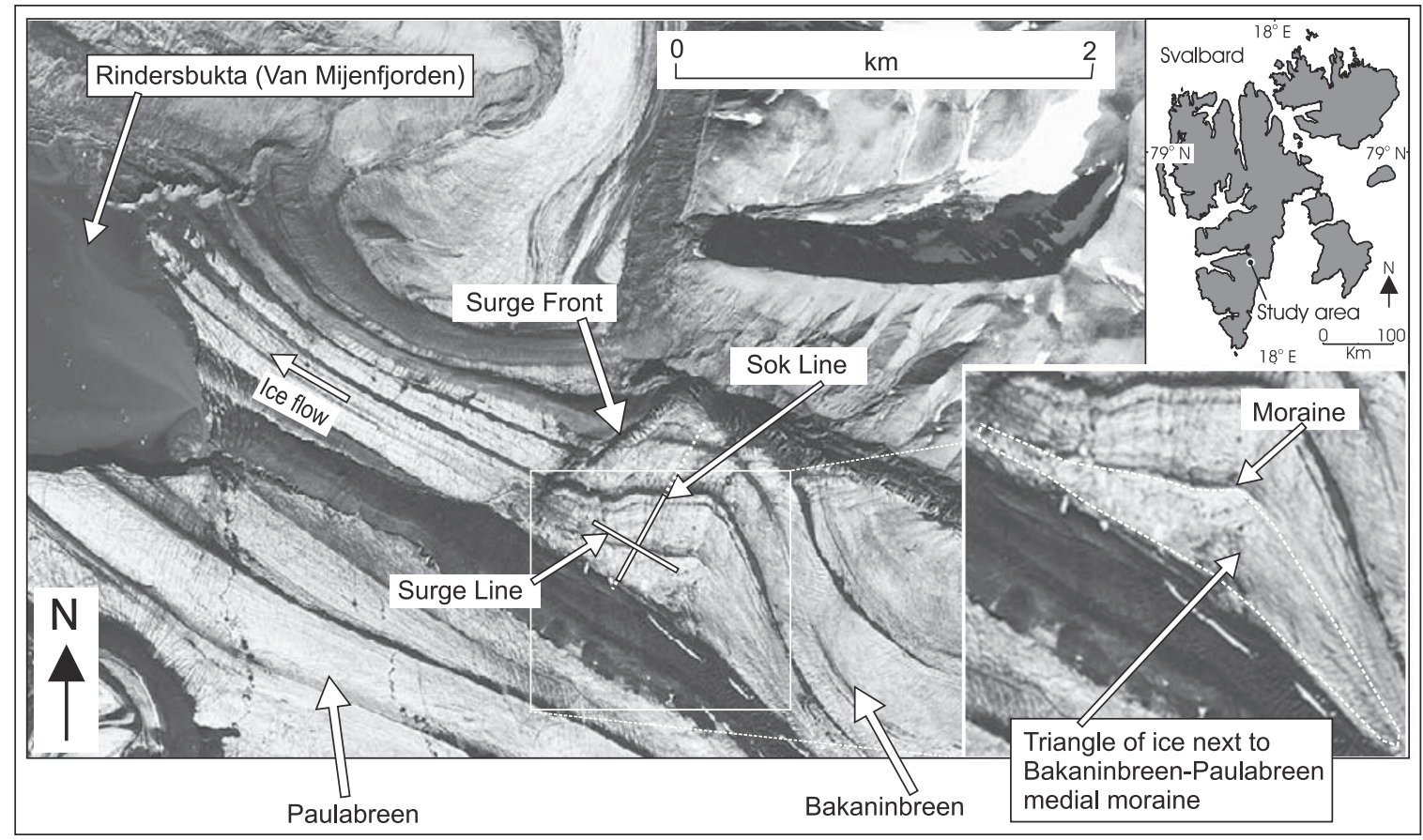

Figure 1. Location map of Bakaninbreen, Svalbard. Positions of the two seismic reflection lines (fourfold data) close to the surge front are indicated. In other figures, data presented from the seismic lines correlate with the solid white lines labeled Surge Line and Sok Line. The northeast and southwest ends of Sok Line (dotted white lines) were only single fold and are not discussed in this paper. The triangle of ice next to the Bakaninbreen-Paulabreen medial moraine is discussed in the text. Subset of aerial photograph S90 6825, copyright Norwegian Polar Institute.

[3] Over recent years, a number of techniques have been used to investigate the glacial and basal conditions of surgetype glaciers [e.g., Kamb et al., 1985; Blake et al., 1992; Clarke and Blake, 1991; Fischer and Clarke, 1994; Hambrey et al., 1996; Murray et al., 1997; Porter et al., 1997; Björnsson, 1998]. These have included surface surveys, glacial geology, hydrology, borehole instrumentation, and ground-penetrating radar (GPR) surveys. We have now combined these techniques with seismic surveys to give further information about the glacier structure, the ice bed interface, and deeper subglacial conditions. We aim to improve our understanding of how these conditions may influence glacier flow and surge characteristics. Of particular interest are the factors controlling surge propagation and termination and the immediate postsurge development at the glacier bed.

[4] Seismic surveys have been applied to many glaciological questions, e.g., identification of deforming and nondeforming ice streambeds [Blankenship et al., 1986; Smith, 1997a], detection of transient changes in basal conditions [Richards, 1988; Nolan and Echelmeyer, 1999], the presence of moraine or fabric changes within the ice [Bentley, 1971; Anandakrishnan et al., 1995], and freezing or melting underneath ice shelves [Herrod, 1986; Smith, 1996]. Here we apply the technique to identify regions of subglacial permafrost and thawed sediment.

\subsection{Bakaninbreen}

[5] Bakaninbreen $\left(77^{\circ} 45^{\prime} \mathrm{N}, 17^{\circ} 16^{\prime} \mathrm{E}\right)$ is a polythermal, surge-type glacier in southern Spitsbergen, Svalbard (Figure 1). It is $\sim 17 \mathrm{~km}$ long and $1-3 \mathrm{~km}$ wide, and ice thickness, at least in the downstream region, is around 50$150 \mathrm{~m}$ [Murray et al., 2000]. The glacier drains ice from accumulation areas in the interior of Heer Land, plus a number of smaller tributary glaciers, into Rindersbukta at the head of Van Mijenfjorden. The glacier is believed to have retreated $\sim 14.5 \mathrm{~km}$ over the past $500-600$ years [Punning et al., 1976] since an earlier surge of the Bakaninbreen-Paulabreen complex, and between 1977 and 1990 retreat of up to $1.4 \mathrm{~km}$ was documented by aerial photography [Dowdeswell et al., 1991; Murray et al., 1998].

[6] Bakaninbreen last began surging in 1985. Ice flow increased rapidly, and the surge was well underway within a year. A surge front up to $60 \mathrm{~m}$ high progressed steadily down the glacier at a rate of up to $1800 \mathrm{~m} \mathrm{yr}^{-1}$ [Murray et al., 1998], until it began to slow down around 1989. From then onward, this slowdown continued, and by 1995 the surge was effectively finished. The glacier terminus was not advanced by the surge. Prior to the surge the glacier is believed to have been warm bedded in its upper regions and cold bedded in its margins and further downstream. A similar thermal distribution is seen today. Upstream of the surge front, the glacier has a thawed bed; downstream it is frozen. This observation led Murray et al. [2000] to suggest that propagation of the surge front was associated with this thermal boundary at the bed. Because the surge front propagated faster than the cold bed could thaw to any great thickness, basal motion must have been restricted close to the ice bed interface. Throughout this paper we will use the term thawed bed (or warm bedded) to refer simply to a basal interface where the ice is not frozen to the substrate. This is not meant to imply anything about conditions beneath that 
interface or the thickness of any underlying layer of thawed sediment. Permafrost or bedrock may lie anywhere between a few centimeters to hundreds of meters below the ice. Likewise, we use the term frozen bed (or cold bedded) for a frozen interface, without implying anything about the thickness of the underlying frozen layer.

[7] The present-day geometry in the downstream part of the glacier is dominated by the surge front [Murray et al., 2000]. This now lies $\sim 1.8 \mathrm{~km}$ from the glacier terminus and is $\sim 60 \mathrm{~m}$ high. Downstream of the surge front the glacier surface rises in a forebulge around $10 \mathrm{~m}$ high, then falls slowly to the glacier terminus. Upstream of the surge front, the surface rises gently, though few measurements have been carried out in recent years on the upper $10 \mathrm{~km}$ of the glacier.

\section{Seismic Data Acquisition and Processing}

[8] A field program of seismic surveys was carried out on Bakaninbreen in March and April 1998 with the aim of investigating the glacial and basal conditions following the end of the surge. Complementary GPR surveys were also conducted at the same time. The early spring weather on the glacier was relatively cold and dry, and the winter snow accumulation was still present on the glacier surface. Compared with summer conditions, these factors enabled improved data quality and eased the acquisition operations. In particular, the radar data were of much better quality than those collected during typical summer conditions, probably due to the absence of free water within the snowpack or at the ice surface.

[9] The seismic lines were positioned just upstream of the surge front (Figure 1). In this region, the period of time since the ice was last flowing fast is less than elsewhere on the glacier. Hence the basal conditions there are most likely to be close to those during the surge. The lines did not extend far down the surge front itself because the seismic reflections from around the glacier bed became increasingly corrupted by ground roll and shear waves as the ice got thinner.

\subsection{Seismic Reflection}

[10] Two orthogonal lines of seismic reflection data were acquired (Figure 1). One crossed the glacier just upstream of the surge front (Sok Line), the other went upstream from the top of the surge front (Surge Line). The middle section of Sok Line and all of Surge Line were acquired as fourfold data. The end sections of Sok Line were both single fold, resulting in significantly poorer data quality, and they will not be discussed further in this paper. Line survey was by conventional surveying, supplemented by GPS position fixes.

[11] The seismic source was $90 \mathrm{~g}$ of Pentolite explosive placed in a 20-m-deep shot hole, drilled with hot water. Shot spacing for the fourfold data was $10 \mathrm{~m}$. The seismic energy was detected by 24 vertically orientated geophones $(40 \mathrm{~Hz}$ natural frequency) with a nominal spacing of $3.3 \mathrm{~m}$. The offset from the shot to the first geophone was $30 \mathrm{~m}$. Data were recorded on a BISON 9024 seismograph. Sample interval was $0.1 \mathrm{~ms}$, and record length was $500 \mathrm{~ms}$. Surge Line was $475 \mathrm{~m}$ long and the fourfold section of Sok Line was $435 \mathrm{~m}$ long.

\subsection{Seismic Refraction}

[12] A Walkaway experiment was carried out parallel to the cross-glacier reflection line (Sok Line) to characterize

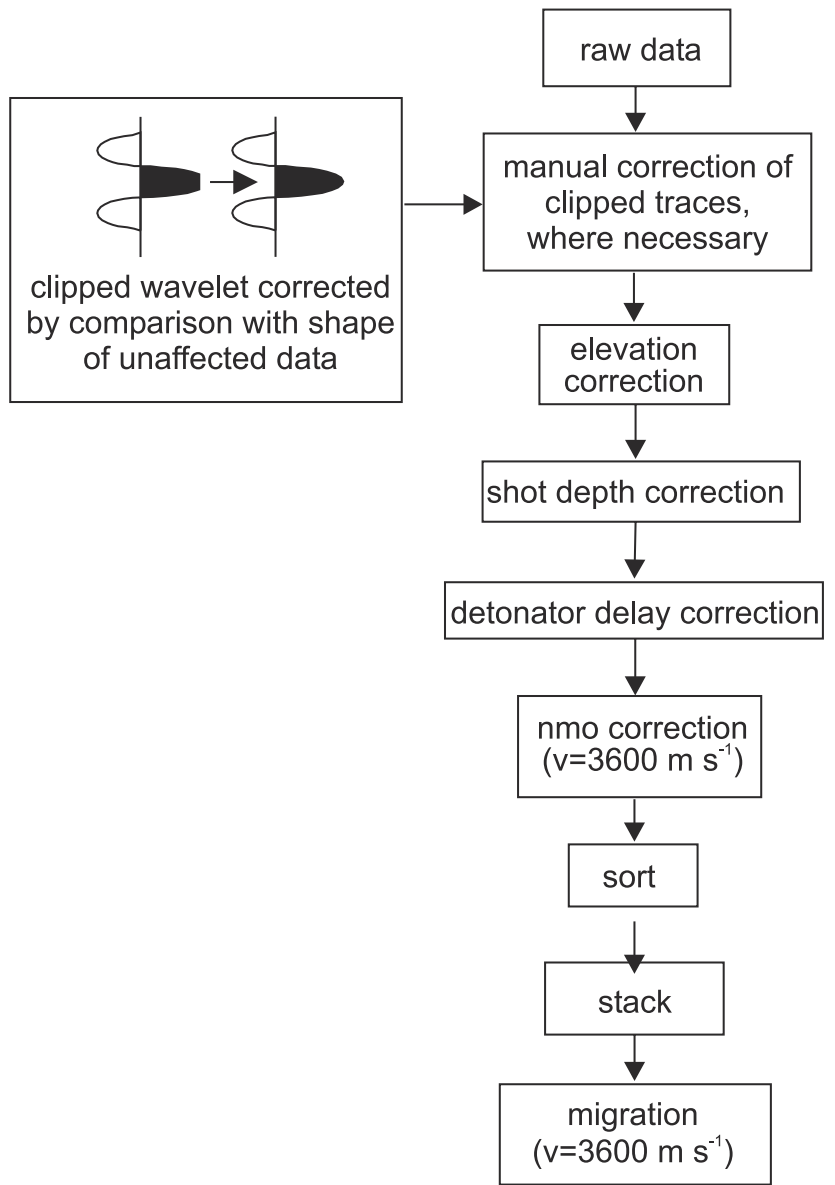

Figure 2. Data processing flow for the seismic reflection data.

the seismic wave field and provide information on the velocity structure within the glacier. A fixed recording array with geophones at $10-\mathrm{m}$ spacing was established partway along Sok Line. Explosive charges (90 g) were detonated at increasing distances from $100 \mathrm{~m}$ out to a maximum offset of $660 \mathrm{~m}$. To determine the shallowest part of the velocity structure, a closer geophone spacing, ranging from 1 to $5 \mathrm{~m}$, was used for another series of shots with source-receiver offsets between 1 and $140 \mathrm{~m}$. For these data a single detonator (explosive content $0.8 \mathrm{~g}$ ) was used as the seismic source. Record lengths for all the refraction shots were $1 \mathrm{~s}$. Shear waves were also recorded, but the results will not be discussed in this paper. Earlier refraction experiments on Bakaninbreen (N. Riley, personal communication, 1998) indicated that there was little variation in the velocity-depth structure with line orientation. Hence the seismic refraction experiments were not reversed.

\subsection{Data Processing}

[13] No processing was required for the seismic refraction data. First-break arrival times were picked and used in the refraction analysis described below. The reflection data were processed using the ProMax system. Details of the processing flow and relevant parameters are given in Figure 2. On 


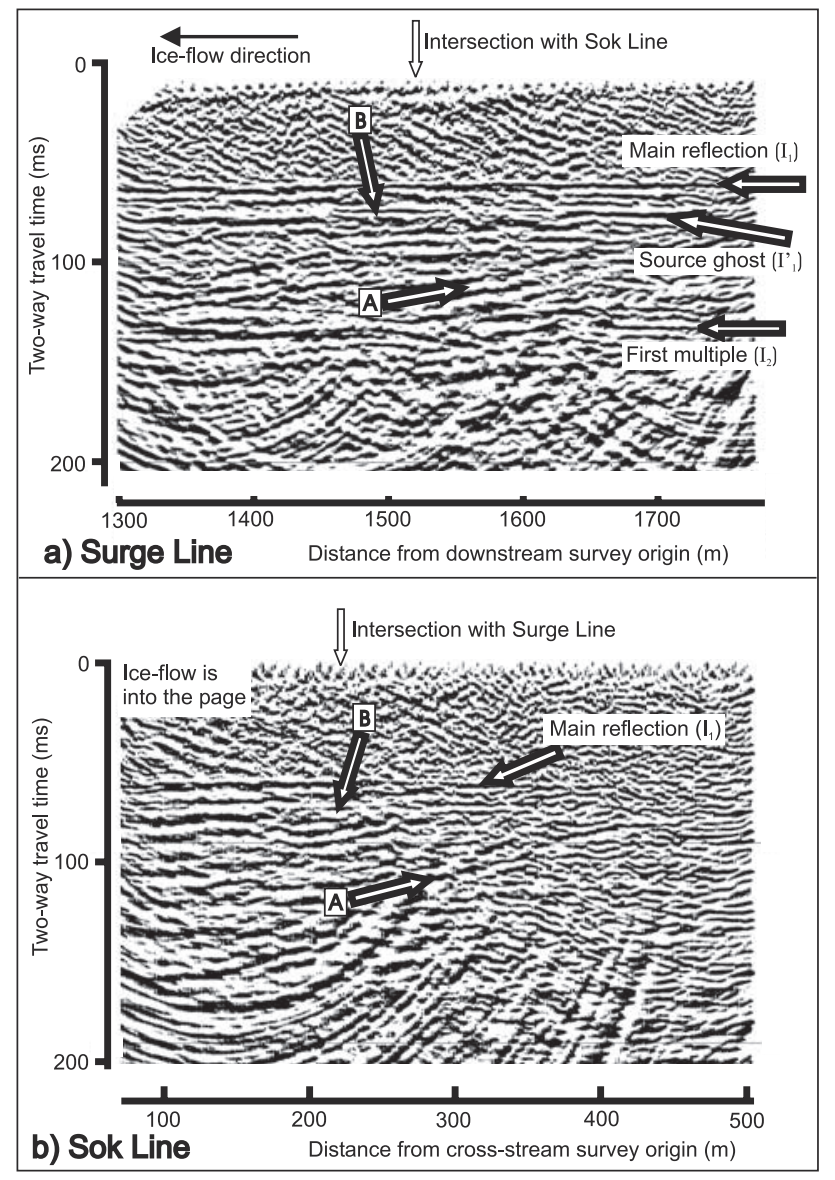

Figure 3. Processed seismic reflection sections (displayed with AGC) for (a) Surge Line and (b) Sok Line. Two-way travel times are below the processing datum $(101 \mathrm{~m}$ above sea level). The various identified reflections are discussed in the text.

some of the traces, the main reflection wavelet was found to be clipped, which had not been identified during the data acquisition. The middle part of the central, main peak (up to a few samples wide) was the only part that was affected. As the amplitude of this wavelet is of particular interest, these short sections of the affected wavelets were re-created manually. This was achieved with reference to the unaffected wavelets and the first arrivals on the refraction data. Those wavelets were found to have relatively simple shape which varies little across the survey area. Hence clipped wavelets were re-created to be a similar shape to the unclipped ones with amplitudes scaled accordingly (Figure $2)$. It is accepted that this may have resulted in a small, additional error, and this is included in the results of the amplitude analysis described later. A shot depth correction of $+7.5 \mathrm{~ms}$ was applied, determined from the seismic refraction data. A correction of $-1.0 \mathrm{~ms}$ was applied for the known delay in the detonators. Although further filtering of the data could have improved the visual quality of the seismic sections, we wished to avoid any modification of amplitude values or first break travel times, so no further processes were applied. The final processed sections are given in Figure 3. Where the two seismic lines intersect, the correlation between the various arrivals is excellent. The comparison between the two lines confirms that arrivals later than the main reflection (see section 7) do come from deeper within the glacier or the bed, rather than from offline reflectors.

\subsection{Main Reflection and First Multiple}

[14] The clearest arrival occurs at a two-way travel time (TWTT) of around $60 \mathrm{~ms}$ (labeled $\mathrm{I}_{1}$ in Figure 3). We know from earlier radar and borehole results [Murray et al., 2000] that this reflection originates at or close to the glacier bed. This main reflection could indicate one of three possible interfaces: the bed itself; the top of a basal ice layer; or the bottom of a subglacial deforming sediment layer. We assume that a basal ice interface would not generate a seismic reflection strong enough to be identifiable on the seismic sections, unless its sediment content was unrealistically high. Hence we discount the possibility that the main reflection represents the top of a basal ice layer. In section 6.2 we show that the reflection coefficient of this interface supports this assumption. We therefore interpret the main reflection as originating from either the glacier bed or the base of a deforming sediment layer at the bed, which overlies deeper subglacial material. Although it varies in strength, the main reflection is of normal polarity all the way along both lines. This indicates an increase in the acoustic impedance (the product of density and seismic velocity) across the associated interface. No coherent arrivals are seen earlier than this main reflection. On parts of Surge Line (Figure 3a) the first multiple of the main reflection $\left(\mathrm{I}_{2}\right)$ can be seen. This is energy which has been multiply reflected between the main reflector and the glacier surface.

\subsection{Source Ghost Reflection}

[15] On seismic data from shots buried more than a few meters below the glacier surface, it is common for the source ghost to be clearly visible. This is energy which travels upward from the shot before bouncing off the surface and going downward, a short time after the initial downward traveling shot energy. From the results of the refraction experiments we expect the ghost to arrive around $13-16 \mathrm{~ms}$ after a primary reflection. The ghost will also be opposite in polarity to the primary reflection and should mimic it closely in the way it varies across the lines. However, although there are arrivals that we identify as the source ghost (e.g., I' ${ }_{1}$ in Figure 3a), it is not as clear as expected, nor is it identifiable everywhere. We attribute this to interference between the ghost and other primary reflections, arriving at about the same time. This is supported by the fact that both the ghost and other arrivals show considerable variability across the seismic sections.

\section{Glacier Structure and Seismic Velocity}

[16] Conversion of reflection travel times to depths requires knowledge of the seismic velocity structure within the glacier. As the radar surveys allow a comparison between the two techniques, the accuracy of the depth conversion of the seismic data is particularly important. Hence a detailed model of the glacier structure and seismic velocity with depth was constructed (Figure 4). This model was based on the refraction experiments combined with 

(and data source)

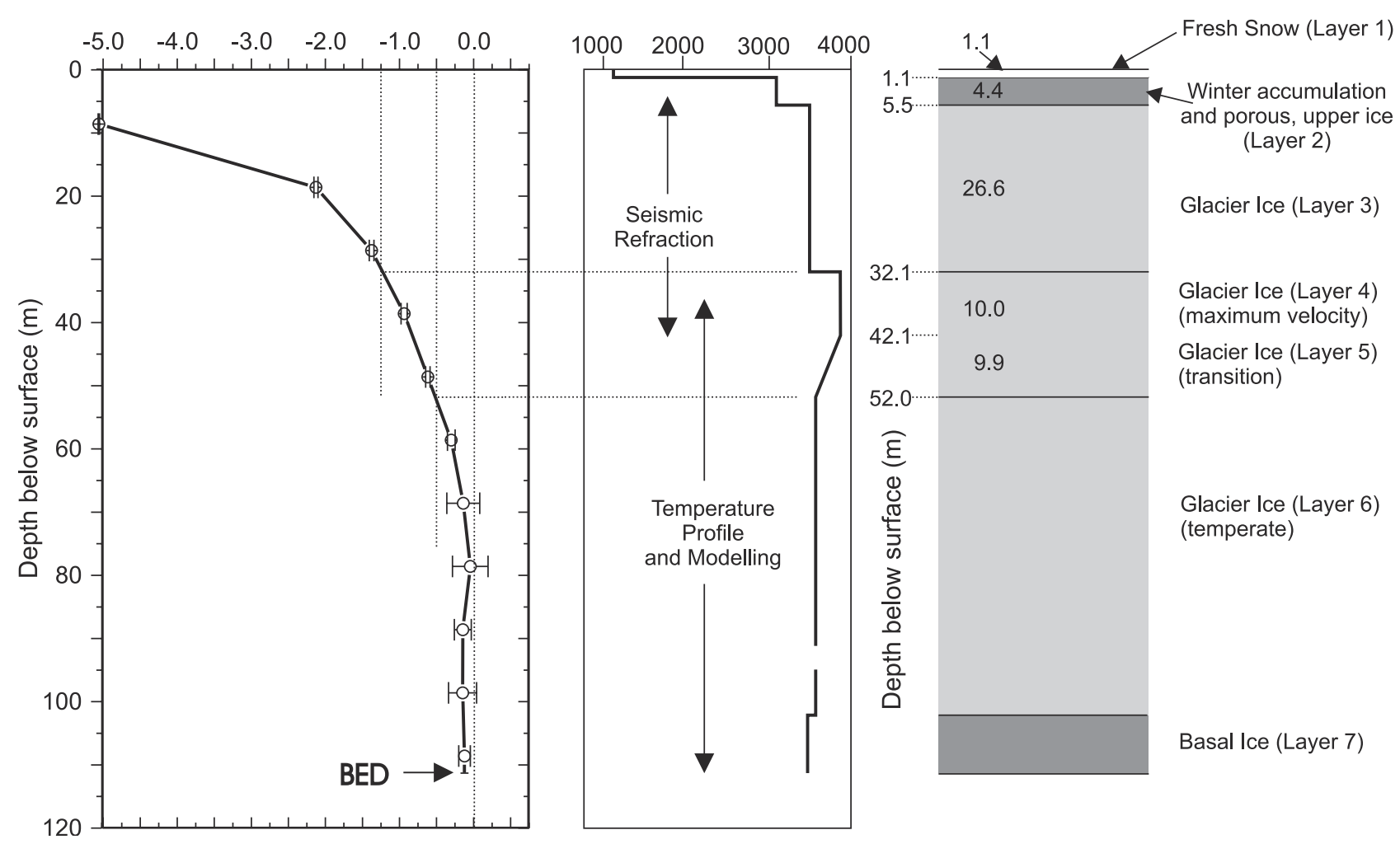

Figure 4. Seismic velocity-depth model and interpretation. The data and methods used to derive the velocities are indicated. The temperature data are taken from Murray et al. [2000].

borehole temperature data and theoretical calculations of the elastic moduli of the very bottom of the ice column.

\subsection{Surface Layers and Glacier Ice}

[17] The seismic velocities and thicknesses of the three upper layers, down to where the maximum seismic velocity is reached, were determined from the refraction data, as was the maximum velocity value itself $\left(3797 \mathrm{~m} \mathrm{~s}^{-1}\right)$. This value is typical of that for relatively cold ice. The refraction data give no results from below the depth where the maximum value is reached. At some point below that depth the velocity is expected to increase in the deeper, warmer ice, and refracted energy cannot be detected at the surface. Hence the deeper part of the velocity-depth profile was determined by reference to the temperature profile within the ice.

[18] The temperature profile from a borehole drilled to the glacier bed close to the seismic lines [Murray et al., 2000] is shown in Figure 4. While the temperature dependence of seismic velocity in cold ice is well documented [Kohnen, 1974], that in temperate ice is less well known. Röthlisberger [1972] summarized the available data, from which Atre and Bentley [1993] concluded that a value for the seismic velocity in temperate ice of $3630 \pm 30 \mathrm{~m} \mathrm{~s}^{-1}$ was the most appropriate. Robin [1958] found that a rapid decrease in seismic velocity with increasing temperature begins somewhere around 0.3 to $0.5^{\circ} \mathrm{C}$ below the pressuremelting point. As Bakaninbreen is relatively thin, the pressure melting point at the bed is effectively $0^{\circ} \mathrm{C}$, and the depth at which the temperature reaches $0.5^{\circ} \mathrm{C}$ below this is $52 \mathrm{~m}$ (Figure 4). Hence we assumed that at this depth the seismic velocity has reduced from its maximum down to a value of $3630 \mathrm{~m} \mathrm{~s}^{-1}$.

[19] The actual velocity profile between the maximum and temperate ice values is difficult to determine, and we represent it by a simple model. There must be some significant thickness of ice in which the seismic velocity is at the maximum value; otherwise, head waves would not propagate to the farthest offsets of the refraction experiments. We allocated a thickness of $10 \mathrm{~m}$ to this maximum velocity ice layer (layer 4 ), this being the mean of the two possible extreme cases. These extreme cases are $0 \mathrm{~m}$ (but then maximum velocity head waves would not have been generated) and $\sim 20 \mathrm{~m}$ (below which the temperature is too warm for such a high velocity value), and they are used to guide the error estimate in section 4.3. Over the remaining transition depth (layer 5), we assumed the velocity decrease is linear. Below $52 \mathrm{~m}$ depth (layer 6), the temperature stays well above $-0.5^{\circ} \mathrm{C}$ (Figure 4 ), so we assumed the typical temperate ice velocity in this layer.

\subsection{Basal Ice}

[20] The only variation in seismic velocity that we expect in the lower part of the glacier is from any layer of basal ice at the bottom. Depending on the nature and concentration of the sediment, basal ice may have a seismic velocity considerably different from sediment-free glacier ice. From a comparison of radar reflections and drill hole depths, 
Murray et al. [2000] proposed that Bakaninbreen may have a layer of sediment-rich basal ice between 5 and 22 m thick. Although there is no evidence for the thickness of this layer in the region of the seismic surveys, we recognized that it may be present and made assumptions about its composition and thickness. It is worth noting that these assumptions have only a minor effect on both the calculated ice thickness and the acoustic properties determined later in the paper.

\subsection{Basal Ice Sediment Content}

[21] There is no evidence for the quantity of sediment within the basal ice on Bakaninbreen, so we made assumptions based on other glaciers. The sediment content in basal ice can be extremely variable. Reported values range from $<1 \%$ to $>70 \%$ by volume between the different facies components of the basal ice [e.g., Echelmeyer and Zhongxiang, 1987; Gow and Meese, 1996; Hart and Waller, 1999; Hubbard and Sharp, 1995; Lawson, 1979; Lawson et al., 1998; Sharp et al., 1994; Sugden et al., 1987]. However, despite this variability, mean sediment concentrations within the full basal ice layer (rather than in component facies layers) normally lie toward the bottom end of the reported range. Hence we took a value of $10 \%$ by volume as a reasonable estimate for the basal ice sediment concentration. Extreme values for this concentration over the full thickness of the basal ice would be $0 \%$ and $20 \%$, and we use these later to guide our estimate of the error in the calculated velocity. We also show in section 6.2 that concentrations higher than this range would be inconsistent with both the observed reflection strengths and the results of borehole drilling.

[22] Hambrey et al. [1996] analyzed sediments believed to have derived from the bed of Bakaninbreen. They described the material as a clast-rich, muddy diamicton and identified the clasts as sandstone and limestone. We made the assumption that the sediment contained in the basal ice is similar in composition to this bed material. We also assumed that half the sediment content by volume is mineral particles (quartz, clay, and calcite, representing the matrix of the diamicton) and that half is in the form of rock particles (sandstone and limestone, representing the clasts).

\subsection{Seismic Velocity and Density in the Basal Ice}

[23] We used the method described by Kuster and Toksöz [1974] to determine the seismic velocity and density in the basal ice. This theory assumes that the sediment inclusions within the ice do not interfere with each other, which is reasonable for the typical concentrations found in basal ice. The elastic moduli and the density of the basal ice are determined using

$$
\begin{aligned}
\frac{K-K_{i}}{3 K+4 \mu} & =c \frac{K_{s}-K_{i}}{3 K_{s}+4 \mu}, \\
\frac{\mu-\mu_{i}}{6 \mu\left(K_{i}+2 \mu\right)+\mu_{i}\left(9 K_{i}+8 \mu\right)} & =\frac{c\left(\mu_{s}-\mu_{i}\right)}{6 \mu_{s}\left(K_{i}+2 \mu_{i}\right)+\mu_{i}\left(9 K_{i}+8 \mu_{i}\right)}, \\
\rho-\rho_{i} & =c\left(\rho_{s}-\rho_{i}\right) .
\end{aligned}
$$

$K_{i}$ is the ice bulk modulus, $\mu_{i}$ is the ice shear modulus, and $\rho_{i}$ is the ice density. $K_{s}, \mu_{s}$, and $\rho_{s}$ are the same parameters for the included sediment; $K, \mu$, and $\rho$ are the effective parameters for the basal ice; and $c$ is the volume
Table 1. Parameters Used to Calculate the Seismic Velocity and Density of the Basal Ice ${ }^{\text {a }}$

\begin{tabular}{lr}
\hline \multicolumn{1}{c}{ Parameter } & Value \\
\hline$K_{i}$ (ice bulk modulus) & $7.47 \mathrm{GPa}$ \\
$\mu_{i}$ (ice shear modulus) & $3.45 \mathrm{GPa}$ \\
$\rho_{i}$ (ice density) & $915 \mathrm{~kg} \mathrm{~m}^{-3}$ \\
$K_{s}$ (sediment bulk modulus) & $23.1 \mathrm{GPa}^{\mathrm{b}}$ \\
$\mu_{s}$ (sediment shear modulus) & $15.7 \mathrm{GPa}^{\mathrm{b}}$ \\
$\rho_{s}$ (sediment density) & $2700 \mathrm{~kg} \mathrm{~m}^{-3 \mathrm{~b}}$ \\
\hline \multicolumn{2}{c}{${ }^{\mathrm{a}}$ Sources: Dvorkin et al. $[1999]$, Mavko et al., [1998], and Carmichael, } \\
[1982]. Ice moduli were calculated assuming a compressional wave seismic \\
velocity typical of temperate ice (3630 m s ${ }^{-1}$ ) and a Poisson's ratio of 0.3 \\
[Röthlisberger, 1972]. \\
bean values of the combined sediment components.
\end{tabular}

concentration of the sediment. Assumed parameters for both ice and sediment are given in Table 1 . The $P$ wave velocity for the basal ice $\left(V_{p}\right)$ can then be calculated from

$$
V_{p}=\left(\frac{K+4 \mu / 3}{\rho}\right)^{1 / 2} .
$$

Hence we determined a seismic velocity $\left(V_{p}\right)$ for the basal ice of $3506 \mathrm{~m} \mathrm{~s}^{-1}$ and a density $(\rho)$ of $1094 \mathrm{~kg} \mathrm{~m}^{-3}$.

\subsection{Basal Ice Thickness}

[24] Murray et al. [2000] estimated the basal ice on Bakaninbreen to be between 5 and $22 \mathrm{~m}$ thick, but there is no evidence for its thickness in the region of the seismic surveys. We assumed a constant basal ice thickness of $10 \mathrm{~m}$ on all the seismic lines (layer 7). The possible errors associated with this assumption are considered in the determination of ice thickness and basal properties later in the paper.

\subsection{Deforming Bed Layer}

[25] Finally, we considered the likely structure within the region of the glacier bed. Various instruments inserted to the bed of Bakaninbreen in the region of the seismic surveys have shown the presence of a thin layer of soft sediment. This layer is believed to be actively deforming in association with the motion of the overlying ice [Porter, 1997; Porter et al., 1997]. We can get some indication of its thickness from the fact that rods inserted into it via boreholes never penetrated more than $50-60 \mathrm{~cm}$.

[26] The acoustic impedance, $Z$, of a material is defined as the product of its density and seismic velocity, and it is a contrast in $Z$ which generates a seismic reflection at an interface. The acoustic impedance of the deforming sediment layer is likely to be close to that of the basal ice [Robin, 1958; Röthlisberger, 1972; Atre and Bentley, 1993]. Hence it is unlikely that we will see a seismic reflection from the ice-sediment interface, particularly as the layer is thin and the level of background noise on the seismic sections is relatively high. In our analysis we therefore assumed a $\sim 50$-cm deforming sediment layer beneath the ice at the glacier bed.

\section{Final Velocity-Depth Model and Estimate of Errors}

\subsection{Velocity-Depth Model}

[27] Figure 4 shows the velocity-depth model with the corresponding interpretation and layer thicknesses. Veloc- 
Table 2. Velocity-Depth Model

\begin{tabular}{|c|c|c|c|c|}
\hline Layer & $\begin{array}{c}\text { Mean Velocity, } \\
\mathrm{m} \mathrm{s}^{-1}\end{array}$ & & $\begin{array}{c}\text { Velocity Error, } \\
\mathrm{m} \mathrm{s}^{-1}\end{array}$ & Thickness, m \\
\hline 1 Fresh snow & 1154 & \multirow{8}{*}{$3756^{\mathrm{a}}$} & \pm 80 & 1.1 \\
\hline 2 Winter snow and upper ice & 3125 & & $\pm<1$ & 4.4 \\
\hline 3 Glacier ice & 3542 & & \pm 64 & 26.6 \\
\hline \multirow{2}{*}{4 Glacier ice } & 3797 & & & 10.0 \\
\hline & & & \pm 100 & \\
\hline 5 Glacier ice & 3714 & & & 9.9 \\
\hline 6 Glacier ice & 3630 & & \pm 30 & typically 68.0 \\
\hline 7 Basal ice & 3506 & & \pm 200 & $10.0^{\mathrm{b}}$ \\
\hline
\end{tabular}

${ }^{\mathrm{a}}$ Mean value of layers 4 and 5 .

${ }^{\mathrm{b}}$ Initial estimate.

ity values are given in Table 2 . We stress that this is only a model and that in places, it might not represent exactly the true velocity values. For example, we expect the velocity in layer 3 (the upper glacier ice layer) to increase gradually toward the maximum value at $32.1 \mathrm{~m}$ depth. However, we believe that mean values within the specified layers are correct and that the model is accurate for the purpose of depth conversion. We used this model along both seismic reflection lines to convert measured travel times to depths. As we wish to compare the seismic data with the GPR results, we now present a detailed consideration of the velocity errors (summarized in Table 2).

\subsection{Errors in the Top Three Layers}

[28] The standard error estimates from linear regression of the refraction data give an indication of the velocity errors in the three upper layers of the model. Earlier, fully reversed seismic refraction experiments on Bakaninbreen (N. Riley, personal communication, 1998) showed only slight velocity differences with shooting direction. To allow for this, we increased the likely velocity error in layer 3 by $\pm 50 \mathrm{~m} \mathrm{~s}^{-1}$.

\subsection{Potential Error Due to Variations in Thermal Structure}

[29] GPR data from Bakaninbreen show internal radar reflectors in the lower part of the ice column [Murray et al., 2000]. These are interpreted as thermal boundaries between upper, cold ice and lower, temperate ice. Within the region where the seismic surveys were conducted, this boundary shows considerable variation. In places it is virtually absent, and cold ice appears to extend down close to the glacier bed. Elsewhere, it rises up to around $26 \mathrm{~m}$ above the bed. Temperature considerations were used to develop parts of the seismic velocity model so we must consider whether the variable radar thermal boundary indicates that a varying seismic velocity model should be used.

[30] In the seismic velocity model, the $-0.5^{\circ} \mathrm{C}$ isotherm was taken to represent the depth at which a typical temperate ice velocity is reached. We will call this isotherm the seismic thermal boundary. The thermal boundaries for the two techniques (seismic and radar) are almost certainly different features. The radar thermal boundary is expected to be within 2-4 $\mathrm{m}$ of the pressure-melting point isotherm $\left(\sim 0^{\circ} \mathrm{C}\right)$ or possibly at some depth below this [Ødegard et al., 1997]. The seismic thermal boundary $\left(-0.5^{\circ} \mathrm{C}\right.$ isotherm) is much higher up within the glacier. Hence the presence of the radar thermal boundary is not necessarily evidence for a varying seismic velocity structure. However, we must consider the possibility that the topography of the radar thermal boundary is mirrored in the seismic boundary higher up. Lowering and raising the seismic thermal boundary by up to $26 \mathrm{~m}$ would affect the calculated ice thickness by $\pm 0.6 \mathrm{~m}$. This is an extreme case which would actually violate the seismic refraction interpretation (the maximum velocity is reached only $20 \mathrm{~m}$ above the seismic thermal boundary). Hence we addressed this potential error by considering layers 4 and 5 together and assigning a mean seismic velocity of $3756 \mathrm{~m} \mathrm{~s}^{-1}$ (Table 2) across the depth range $32.1-52.0 \mathrm{~m}$. We then assigned an error to this value of $\pm 100 \mathrm{~m} \mathrm{~s}^{-1}$, which would roughly represent either a maximum $\left(3797 \mathrm{~m} \mathrm{~s}^{-1}\right)$ or a minimum $\left(3630 \mathrm{~m} \mathrm{~s}^{-1}\right)$ velocity value occurring over the whole of this depth range. This approach to the error associated with the thermal boundary also covers the possibility that the change in seismic velocity occurs closer to $-0.3^{\circ} \mathrm{C}$ than $-0.5^{\circ} \mathrm{C}$ (the value we assumed).

\subsection{Basal Ice Layer Velocity Error}

[31] As with the thermal boundary variability, we assessed the error estimate in the basal ice velocity by considering the possible extreme cases. If no basal ice layer is present, our velocity estimate for the lowest $10 \mathrm{~m}$ of the glacier would be $124 \mathrm{~m} \mathrm{~s}^{-1}$ too low. If there are $20 \mathrm{~m}$ of basal ice, our velocity estimate over that depth would be 62 $\mathrm{m} \mathrm{s}^{-1}$ too high. Alternatively, if the sediment content is as high as $20 \%$ by volume, our velocity would be around $72 \mathrm{~m}$ $\mathrm{s}^{-1}$ too high. Allowing for uncertainty in the chosen sediment composition and the assumed deforming sediment layer suggests a maximum error in the basal ice velocity of $\pm 200 \mathrm{~m} \mathrm{~s}^{-1}$.

\section{Ice Thickness}

\subsection{Reflector Depths and Corresponding Errors}

[32] Two-way travel times to the first break of the main reflection were picked along both seismic reflection lines. The elevation correction applied in the data processing was then removed and the velocity-depth model was used to convert the travel times to depths below the surface. Figure 5 shows the ice thickness (including any thin deforming bed) along both seismic lines, which varies between 105 and 129 $\mathrm{m}$. Standard error estimates for these depth values were determined from the errors in the seismic velocities (Table 2) combined with those in the detonators $( \pm 0.5 \mathrm{~ms})$, the travel time picks $( \pm 0.1 \mathrm{~ms})$ and the shot depth correction $( \pm 1.0 \mathrm{~ms})$. 

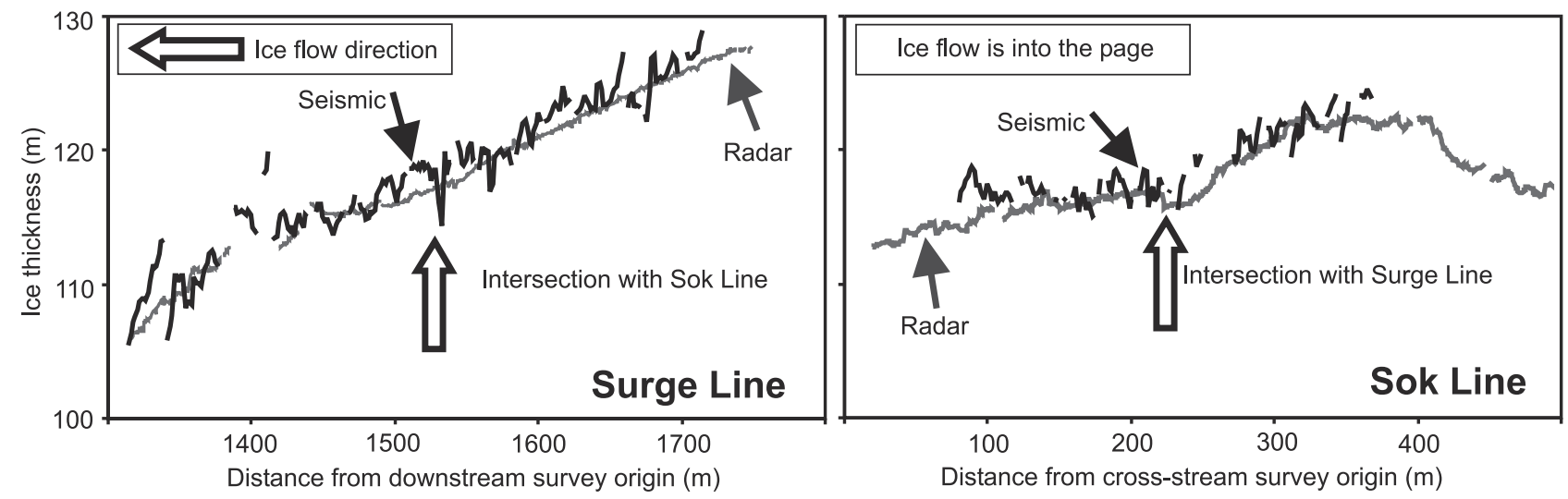

Figure 5. Ice thickness along both lines determined from the seismic data (solid lines). Corresponding measurements from the radar data (shaded lines) are also shown.

This gives an error in the depth to the main seismic reflection of $\pm 2.6 \mathrm{~m}$.

\subsection{Coincident Radar Data}

[33] Some of the radar data collected during the fieldwork have been presented by Murray et al. [2000]. In Figure 6 we reproduce the section of those data coincident with Surge Line and present the radar data which coincide with Sok Line. (See Murray et al. [2000] for details of acquisition, data processing and analysis.) Murray et al. [2000] concluded that the main radar reflector was not the glacier bed but rather the top of a basal ice layer. Depths to the main radar reflection have been calculated using a depth-averaged velocity $(165 \mathrm{~m}$ $\mathrm{ns}^{-1}$ ) determined from semblance analysis of common midpoint surveys [Murray et al., 2000]. A comparison between the seismic and radar depths, where the two data sets overlap, is shown in Figure 5. Errors on the radar values were also estimated from the semblance analysis and are approximately $\pm 1 \mathrm{~m}$. Along most of the lines, there is no significant difference between the two sets of measurements. We conclude that the basal ice layer in the region of the seismic surveys is no thicker than around $5 \mathrm{~m}$ and may even be absent.

[34] In contrast to our results, Drewry [1987] reported significant differences between seismic and radar-derived ice thickness on Bakaninbreen, which he suggested could be caused by a considerable thickness of basal till. Unfortunately, few details were given but a thick basal ice layer in the regions of Drewry's surveys is another possible explanation for his observations.

\section{Bed Material and Basal Conditions}

\subsection{Seismic Reflection Coefficient}

[35] We have interpreted the main seismic reflector as the glacier bed or else the base of a thin deforming sediment layer at the glacier bed, overlying deeper subglacial material. We now consider the strength of this reflection, the way it varies across the seismic reflection lines and the implications for the deeper subglacial material and conditions. The energy, $E_{1}$, of the main seismic reflection is given by Röthlisberger [1972]:

$$
E_{1}=\frac{E_{0} R^{2}}{4 h^{2}} e^{-2 a h},
$$

where $E_{0}$ is the initial energy at the source, $R$ is the reflection coefficient at the interface, $h$ is ice thickness, and

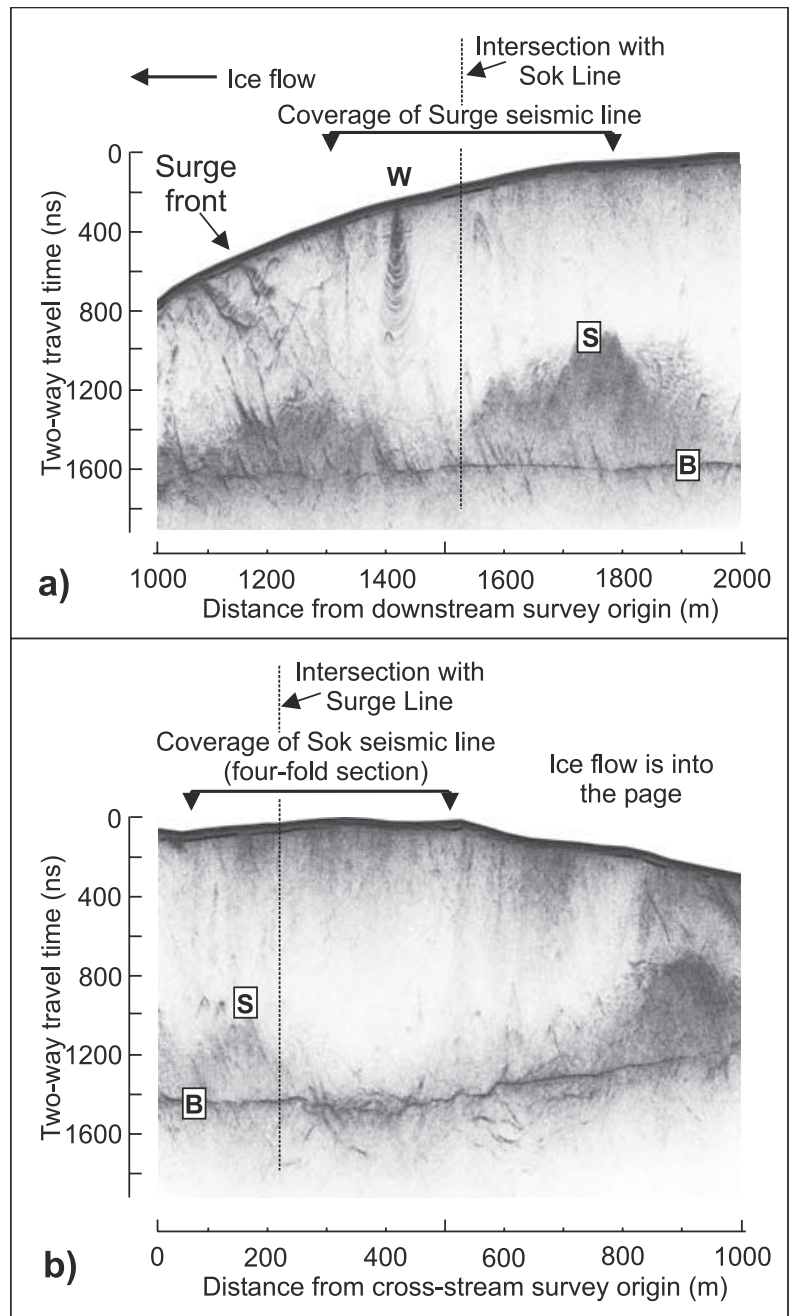

Figure 6. GPR sections coincident with the seismic reflection lines. (a) Surge Line, extracted from Figure 6 of Murray et al. [2000]. (b) Sok Line. Data acquisition and processing are the same as for those presented by Murray et al. [2000], except that these are displayed with a constant gain, rather than an AGC. $\mathrm{S}$ is the cold-warm ice interface interpreted by Murray et al. [2000]. B is the main radar reflection. $\mathrm{W}$ marks the position of a borehole containing wire. 

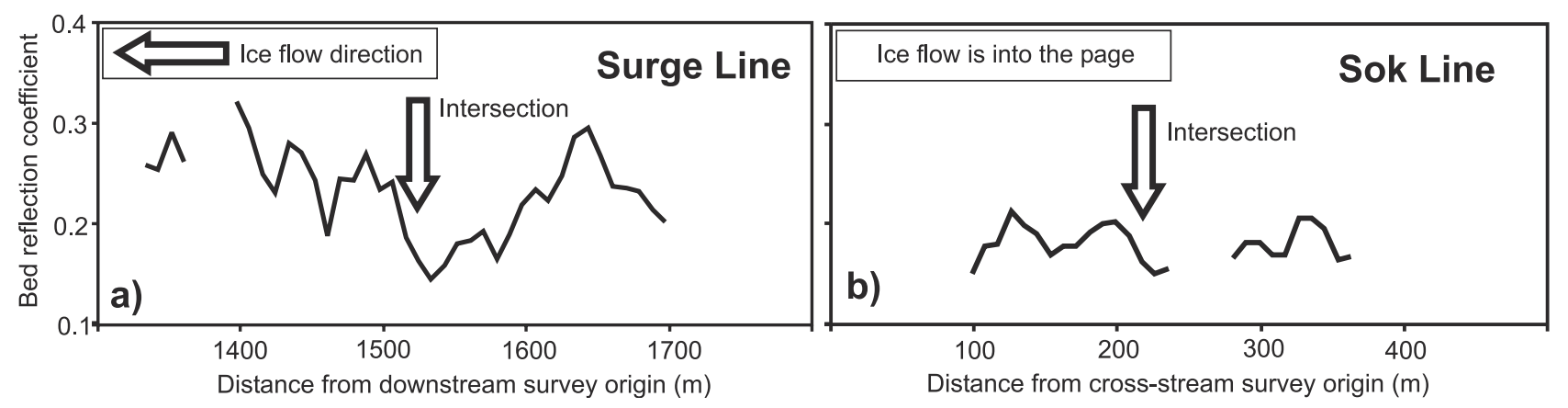

Figure 7. Reflection coefficient of the main reflecting interface along (a) Surge Line and (b) Sok Line.

$a$ is the attenuation within the ice. Assuming that the reflection coefficient at the glacier surface is -1 , the change in energy between the main reflection and its first multiple is given by

$$
\frac{E_{1}}{E_{2}}=\frac{4}{R^{2}} e^{2 a h},
$$

where $E_{2}$ is the wavelet energy of the multiple. The record length for all the seismic reflection shots was sufficient to record both the main reflection $\left(\mathrm{I}_{1}\right)$ and its first multiple $\left(\mathrm{I}_{2}\right)$. The multiple can be seen on the seismic section for Surge Line (Figure 3a), corresponding to the location of seven separate shots. Identification of the multiple was confirmed by prediction from the travel time of the main reflection and, in some cases, the presence of the associated source ghost multiple. In this way, possible confusion with other arrivals was eliminated.

[36] The wavelet of the main reflection appears to be a fairly simple, symmetrical shape, comprising three lobes: a central main one with two lesser-amplitude side lobes (Figure 2). As there appear to be a few places where the main reflection is followed closely by later arrivals, we used only the central lobe of a wavelet to measure its strength. To improve the reliability of the reflection strength measurements, amplitude values were measured from the averages of four adjacent traces.

[37] At each location where the multiple was identified, the energies of the main reflection and its multiple were determined from the sum of the squared amplitude values for each wavelet. The reflection coefficient was then calculated at each location from equation (4). An attenuation value of $1.5 \times 10^{-3} \mathrm{~m}^{-1}$ was used, suitable for ice where the mean annual temperature is around $-10^{\circ} \mathrm{C}$ [Jarvis and King, 1993]. The reflection coefficient, $R_{s}$, at any point along Surge Line is given by

$$
R_{s}^{2}=\frac{R_{m}^{2} E_{1 s} h_{s}^{2}}{E_{1 m} h_{m}^{2}} e^{2 a\left(h_{s}-h_{m}\right)},
$$

where subscript $m$ denotes parameters at one of the locations where the multiple was measured and $h_{s}$ and $E_{1 s}$ are the ice thickness and $\mathrm{I}_{1}$ energy, respectively, at the point where $R_{s}$ is to be determined [Smith, 1997a]. The derivation of equation (5) assumes that the initial energy is the same for each shot. As the charge sizes were placed at the same depth within the glacier ice in water-filled holes, this is a reasonable assumption. Concentrations of sediment within the glacier could cause some variability in the amount of energy imparted in to the ice; however, there is no evidence for this on the radar data, which are normally very effective at identifying even small quantities of englacial sediment [e.g., Murray et al., 1997]. Also, the process of stacking the fourfold seismic data will have smoothed out any small variations which may exist between shots. The basal reflection coefficient $\left(R_{S}\right)$ along the whole of Surge Line was calculated using equation (5) for each of the seven sets of $R_{m}, E_{1 m}$, and $h_{m}$ values. The mean of these was then taken. No clear multiples can be identified on Sok Line, so the mean reflection coefficients there were determined from the intersection with Surge Line. Reflection coefficients for both seismic lines are given in Figure 7 and range between $\sim 0.14$ and $\sim 0.32$. An estimate of the error in the reflection coefficient can be obtained from the RMS error in the seven separate determinations of $R_{S}$ on Surge Line. This suggests a maximum likely error of around ${ }_{-0.029}^{+0.036}$, although as it varies with the magnitude of $R_{s}$, in most places it is expected to be significantly less than this.

\subsection{Reflection Coefficients and Basal Ice}

[38] Gaps in the reflection coefficient data occur where wavelet amplitudes could not be measured with confidence. In some places (in the middle of Sok Line, for example) this was because the amplitudes were too low relative to the background noise (Figure 3b), suggesting that interfaces with $R$ of less than around 0.14 will not generate strong enough reflections to be identifiable. Elsewhere, they were due to interference or noise (e.g., toward the downstream end of Surge Line). The reflection coefficient at the interface between two layers is related to their acoustic impedance values by

$$
R=\frac{Z_{2}-Z_{1}}{Z_{2}+Z_{1}}
$$

where subscripts 1 and 2 refer to the upper and lower layers, respectively. For the reflection from a clean ice-basal ice interface to be just visible, the impedance of the basal ice would have to be greater than around $4.4 \times 10^{6} \mathrm{~kg} \mathrm{~m}^{-2}$ $\mathrm{s}^{-1}$. Equation (1) indicates that this would require a mean sediment content considerably greater than $20 \%$ over a thickness of at least many meters. For basal ice to give rise to the highest reflection coefficient values in Figure 7 would require mean sediment contents of around $50 \%$ or more. These sediment concentrations are unrealistically 


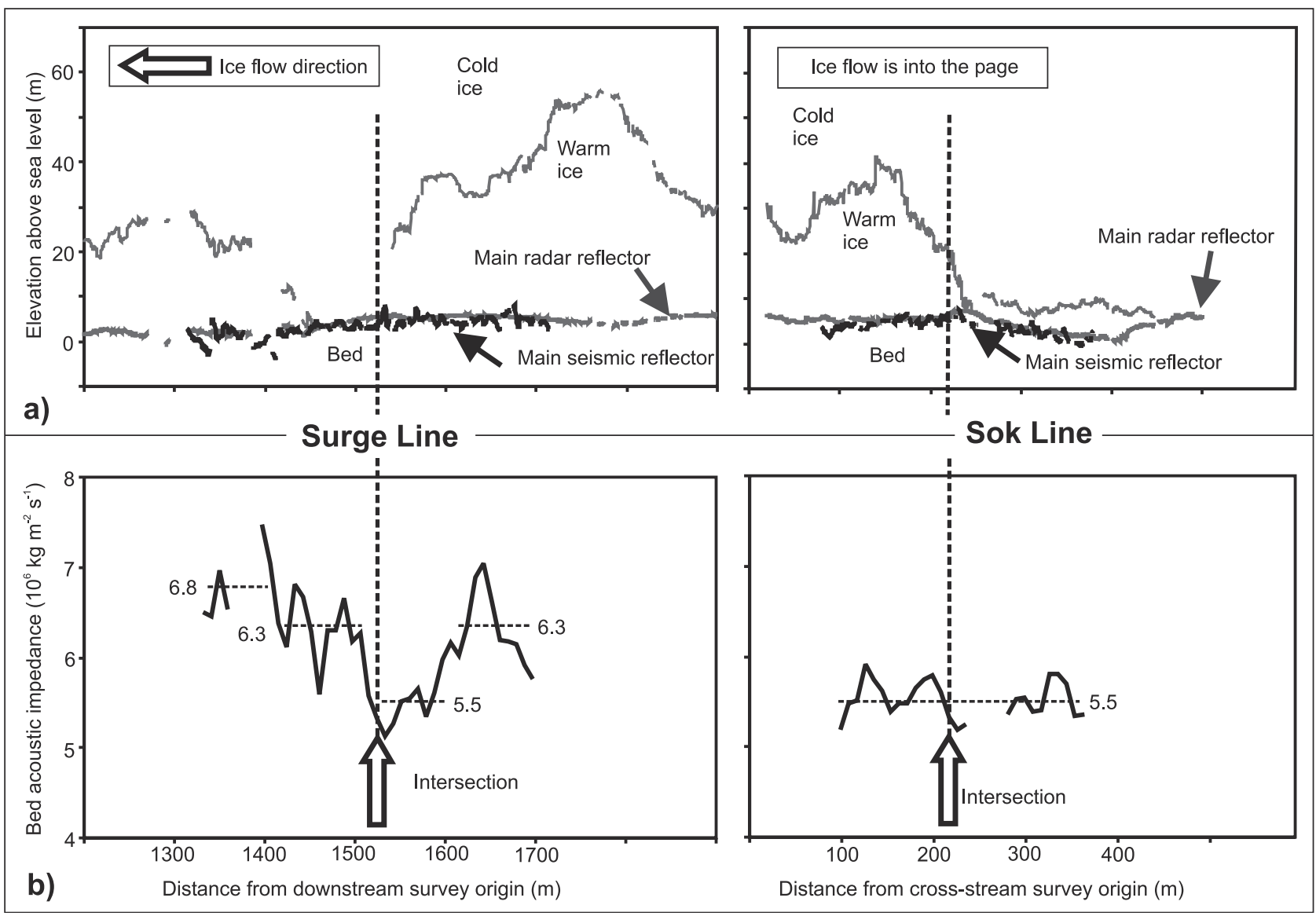

Figure 8. (a) Elevations of interpreted seismic and GPR reflecting horizons in the region of the seismic lines. (b) Acoustic impedance of the bed material derived from the analysis of the seismic reflection data. To simplify the interpretation, mean values in four regions of Surge Line and the whole of Sok Line are indicated.

high. It is also unlikely that a hot water drill could successfully penetrate such a layer due to the inability to remove the high concentrations of sediment from the hole, but many holes have successfully reached the bed of the glacier [Porter, 1997; Porter et al., 1997]. Hence we are confident that the main seismic reflection does not arise from the top of a basal ice layer but rather from a deeper interface.

\subsection{Acoustic Impedance of the Bed Material}

[39] Knowing the reflection coefficient at the main seismic interface (Figure 7), the acoustic impedance of the material beneath it can be determined from equation (6), provided the impedance of the medium above the interface is known. The seismic velocity and density of the basal ice were determined to be $3506 \mathrm{~m} \mathrm{~s}^{-1}$ and $1094 \mathrm{~kg}$ $\mathrm{m}^{-3}$, respectively, giving an impedance of $3.84 \times 10^{6} \mathrm{~kg}$ $\mathrm{m}^{-2} \mathrm{~s}^{-1}$. The resulting acoustic impedance for the material beneath the main reflector is shown in Figure 8 and varies between $\sim 5.0 \times 10^{6}$ and $7.5 \times 10^{6} \mathrm{~kg} \mathrm{~m}^{-2} \mathrm{~s}^{-1}$. From now on we will refer to this material as the bed, though we reiterate that it may be separated from the bottom of the glacier by a thin layer of deforming sediment. For comparison, Figure 8 also shows the elevations of the main seismic and radar reflectors and the approximate elevation of the cold ice-warm ice interface seen on the radar data (Figure 6).

\subsection{Errors in the Basal Acoustic Impedance}

[40] The error in the acoustic impedance of the bed is dominated by that in the calculated reflection coefficient, $R$. This combines with the uncertainty in the acoustic impedance of the basal ice to suggest a maximum likely error in $Z_{b}$ of around ${ }_{-0.5}^{+0.7} \times 10^{6} \mathrm{~kg} \mathrm{~m}^{-2} \mathrm{~s}^{-1}$. The error in $Z_{b}$ will increase with the magnitude of $R$, and in most places, it is expected to be significantly less than this value.

\subsection{What is the Bed Material?}

[41] In Figure 8 we have divided the bed into regions of relatively high, medium, and low impedance to allow a broad interpretation of the results. In each region, mean impedance values were calculated $\left(6.8 \times 10^{6}, 6.3 \times 10^{6}\right.$, and $5.5 \times 10^{6} \mathrm{~kg} \mathrm{~m}^{-2} \mathrm{~s}^{-1}$, respectively). Possible materials beneath the glacier include thawed sediment, permafrost, and bedrock. Data on the seismic velocity and density of permafrost are scarce. Figure 9 shows data reported by a number of authors [Röthlisberger, 1972; Robin, 1958; Eiken, 1994; Kurfurst, 1976; Zimmerman and King, 1986]. For some of these samples, no density values were given. In these cases, density was calculated from quoted values of porosity, saturation, and seismic velocity, follow- 


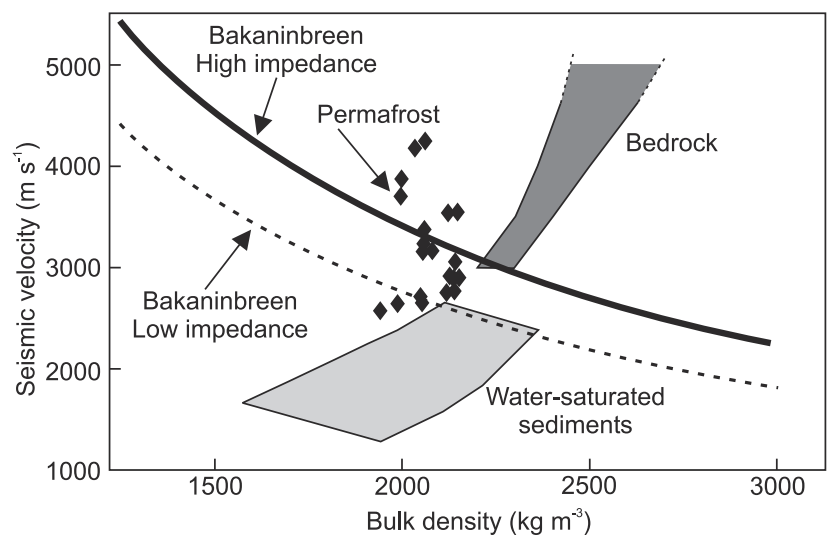

Figure 9. Curves of constant acoustic impedance from different parts of the bed of Bakaninbreen, in the area of the seismic surveys. High $\left(6.8 \times 10^{6} \mathrm{~kg} \mathrm{~m}^{-2} \mathrm{~s}^{-1}\right)$ and low $\left(5.5 \times 10^{6} \mathrm{~kg} \mathrm{~m}^{-2} \mathrm{~s}^{-1}\right)$ impedance values are shown. The curves are compared with typical velocity and density values for permafrost, local bedrock, and soft, watersaturated sediments. Data sources are given in the text.

ing the method of Zimmerman and King [1986]. Local bedrock in the Bakaninbreen area is Lower Cretaceous sandstones and shales [Dallman et al., 1993], for which typical velocity and density values were taken from Gardner et al. [1974]. Values typical of the bedrock in this region of Svalbard were also taken from Eiken [1994]. The range of values for bedrock is shown in Figure 9, as are typical velocity and density values for soft, water-saturated sediments [Barrett and Froggatt, 1978; Hamilton, 1970; Morgan, 1969; Nafe and Drake, 1963; Smith, 1997a, 2000]. These data are compared with curves of constant acoustic impedance from the different regions of the bed of Bakaninbreen, in the region of the seismic surveys. High $(6.8 \times$ $\left.10^{6} \mathrm{~kg} \mathrm{~m}^{-2} \mathrm{~s}^{-1}\right)$ and low $\left(5.5 \times 10^{6} \mathrm{~kg} \mathrm{~m}^{-2} \mathrm{~s}^{-1}\right)$ impedance values are shown.

[42] The high impedance values intersect the middle of the range for permafrost and the very lowest end of the range for the local bedrock. Hence it is most likely that these values indicate permafrost beneath the glacier. The low impedance values intersect the upper end of the thawed sediment range as well as the lower end of the permafrost range. Hence we interpret the low impedance areas as thawed sediment, possibly including some thin or discontinuous patches of permafrost. Regions where the main reflection was too weak for its energy to be measured accurately (e.g., the middle of Sok Line) probably indicate thawed sediment with little or no permafrost present. We interpret the areas of medium impedance as transitional between the other two bed types: significant patches of permafrost are interspersed within a thawed sediment bed. Beneath the permafrost we expect thawed sediment overlying bedrock. It is worth noting that even if we consider the maximum likely errors in the calculated acoustic impedance values (which include the uncertainties in basal ice thickness and sediment content), this interpretation remains unchanged: the high impedance values are still most likely to be permafrost, while the low values are most likely to be water-saturated sediments, possibly with patches of permafrost.
[43] This interpretation of the impedance pattern at the glacier bed (Figure 8) suggests the presence of a significant thickness of permafrost at the downstream end of Surge Line, that is, close to the surge front itself. Farther upstream, the permafrost becomes thinner and/or discontinuous, becoming virtually absent just over halfway along the line. At the upstream end of Surge Line, patches of permafrost become more prevalent, or thicker once more. The pattern on Sok Line is much simpler. All the way along, the bed is composed of thawed sediments, possibly with patches of thin or discontinuous permafrost. Near the middle of the line, there may even be no permafrost present and the sediment could be softer or more water-saturated than elsewhere.

\subsection{Comparison With Previous Interpretations}

[44] It is interesting to note that on Surge Line the regions dominated by permafrost lie beneath the areas where the warm ice is thickest. In contrast, the interpretation of Murray et al. [2000] shows permafrost beneath thin, cold ice and thawed bed beneath polythermal ice. Our interpretation does not contradict that of Murray et al. [2000] but complements it by providing a more detailed analysis of a small section of their line. We stress that the ice bed interface in the region of our seismic lines is thawed. This correlates with part of Murray et al.'s thawed bed interface upstream of the surge front, rather than their cold ice frozen to a permafrost bed downstream of it. As the seismic surveys coincide with only a small part of the surveys of Murray et al. [2000], the variable topography of the cold ice-warm ice boundary is much more obvious in our Figure 8 than in their figures. However, in both interpretations this is considered to be simply variability within the overall thawed bed regime found upstream of the surge front.

[45] The permafrost we have identified lies beneath the thin, thawed sediment layer which may be anything up to 50 $\mathrm{cm}$ thick. The correlation between the permafrost and thicker, warm ice may be coincidental as the thermal distribution within the ice at this point will be a relatively recent feature, related to the progression of the surge front, whereas the permafrost will have been present during the long period of quiescence before the surge.

\subsection{Correlation With Glacier Dynamics}

[46] The 1990 aerial photograph of Bakaninbreen (Figure 1) shows a pattern of moraines at the glacier surface. The radar data show no indication that these extend to any significant depth within the ice. Even if they do, they are unlikely to be extensive laterally and would not cause any significant variability in the acoustic impedance of the basal ice. Hence we conclude that these surface moraines do not influence the analysis of the seismic data. They do, however, appear to give some indication of different flow units in the glacier. The intersection of the seismic reflection lines coincides with one of these moraines. The small region of ice between this moraine and the Bakaninbreen-Paulabreen medial moraine appears to thin laterally both upstream and downstream, forming a triangular area of ice (Figure 1). In their analysis of the structural glaciology of Bakaninbreen, Hambrey et al. [1996] did not consider this area to be a significant flow unit. It is possible that in some way the dynamic history of this region of ice during the surge may 
have differed from the rest of the glacier. Shearing between this region and adjacent ice may have been a source of heat responsible for some of the variability in the warm ice-cold ice interface identified on the radar data (Figure 6). There may also have been different degrees of interaction between the glacier and the bed on either side of this moraine during the late stages of the surge. Further investigations would be required to clarify the significance of this observation.

\section{Subbasal Structure and Conditions}

[47] The seismic reflection sections from the two lines (Figure 3) contain a number of coherent arrivals later than the main reflection. In general, they are more discontinuous and suffer more interference from noise and other arrivals than the main reflection. However, they can be used to give some indication of the possible deeper structure and conditions.

\subsection{Bedrock}

[48] On both seismic reflection sections (Figure 3), coherent dipping arrivals (labeled A) are visible between around 20 and $60 \mathrm{~ms}$ deeper than the main bed reflection. The sections are displayed with an automatic gain control (AGC) which has the effect of amplifying weaker arrivals. Without the AGC, these dipping arrivals are still strong and clear, confirming that they are significant reflecting interfaces. The dip directions on both sections are consistent with the WSW trend of the regional bedrock dips [Dallmann et al., 1993; Salvigsen and Wisnes, 1989], and we interpret them as bedding (or other bed-parallel planes) within the bedrock. Assuming a bedrock seismic velocity of $\sim 3500 \mathrm{~m} \mathrm{~s}^{-1}$ (Figure 9) suggests that we are imaging up to around $100 \mathrm{~m}$ into the bed.

\subsection{Permafrost and Sediment Thickness}

[49] From the seismic data we have interpreted a variable layer of permafrost, overlying thawed sediments and bedrock. It is possible that sediment-permafrost and bedrock-permafrost interfaces may result in only weak reflections, owing to the relatively low impedance contrasts (Figure 9) and the possibility of gradational interfaces. However, we would expect to see a stronger reflection from a sediment-bedrock interface. There is little evidence for this arrival on either of the seismic sections. This may be due to interference with the source ghost reflection, another arrival which is surprisingly hard to identify. These two reflections may arrive at around the same time. They could be of similar strengths and opposite polarities (the ghost being reversed and the bedrock normal), and interference between the two may mask a clear arrival from either. There is, however, one arrival beneath the main reflection which is particularly clear. This is labeled B in Figure 3 and occurs at the intersection of the two seismic lines, where the bed is interpreted to be thawed sediment with little or no permafrost. Although continuous across only a relatively short distance (around $100 \mathrm{~m}$ on Surge Line and $25 \mathrm{~m}$ on Sok Line), this arrival is clearly strong and normal polarity. This is most likely to represent a boundary between thawed sediment and bedrock, but it is possible that it could be sediment overlying a deeper permafrost layer. By

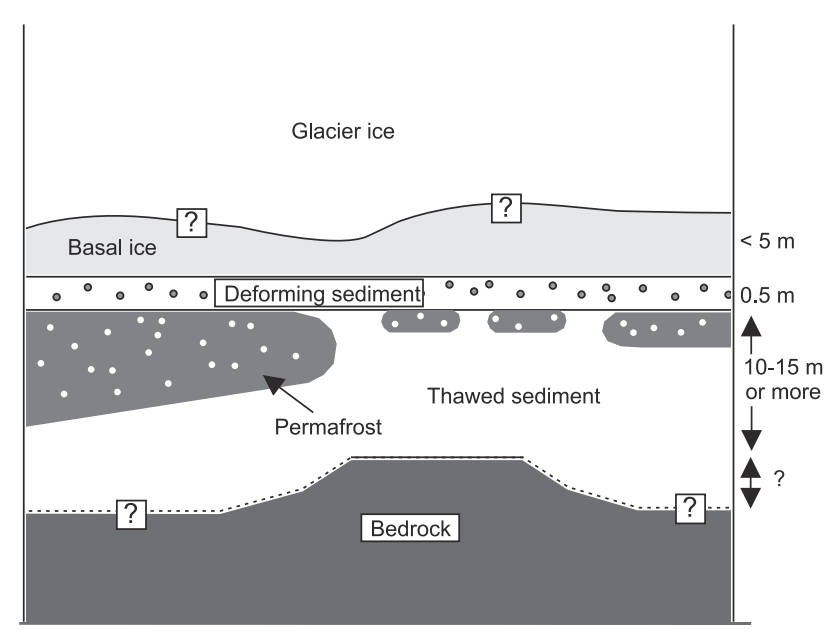

Figure 10. Interpretation of late surge glacial and subglacial structure beneath Surge Line.

using the same technique we used to calculate the reflection coefficient at the bed, we determined an apparent reflection coefficient for this interface $\left(R_{B}\right)$ of around 0.15 . This will almost certainly not be a true reflection coefficient at interface $B$ due to reflections and attenuation within the bed above it. However, as both these factors will lead to the value of $R_{B}$ being underestimated, we can use this as a minimum value at this point. We assumed typical acoustic impedance values for thawed sediment, permafrost and bedrock of $5.5 \times 10^{6}, 6.8 \times 10^{6}$, and $8.3 \times$ $10^{6} \mathrm{~kg} \mathrm{~m}^{-2} \mathrm{~s}^{-1}$, respectively. From equation (3) we expect $R_{B}$ for a sediment-permafrost interface to be around 0.11 , while for sediment-bedrock we expect $R_{B}$ to be around 0.20 . Hence it is more likely that reflection $\mathrm{B}$ represents thawed sediment overlying local bedrock. Two-way travel time between the main reflection and $\mathrm{B}$ is around $10-13 \mathrm{~ms}$ suggesting that the sediment layer is around $10-15 \mathrm{~m}$ thick at this point. Our interpretation of the present-day subglacial structure on Bakaninbreen beneath Surge Line is summarized in Figure 10.

\section{Implications for Surge Termination}

8.1. Water Escape Through Discontinuous Permafrost

[50] The identification of discontinuous permafrost beneath the surge front on Bakaninbreen suggests a mechanism for the termination of the surge (Figure 11). Permafrost underlying a thin deforming sediment layer at the glacier bed would probably form an impermeable seal to any subglacial drainage. Murray et al. [2000] showed that the propagation of the surge front was probably associated with the progressive thawing of a frozen ice bed interface. Upstream of the surge front, this produced a thin, thawed sediment layer between the ice and the underlying permafrost. Water generated by melting of the ice or drainage from further upstream would therefore remain trapped between ice and permafrost. This could keep the water pressure within the sediment relatively high, which may be an important factor in maintaining surge propagation [Murray et al., 2000]. The surge may then only have terminated when some route became available for the subglacial water to escape from the 


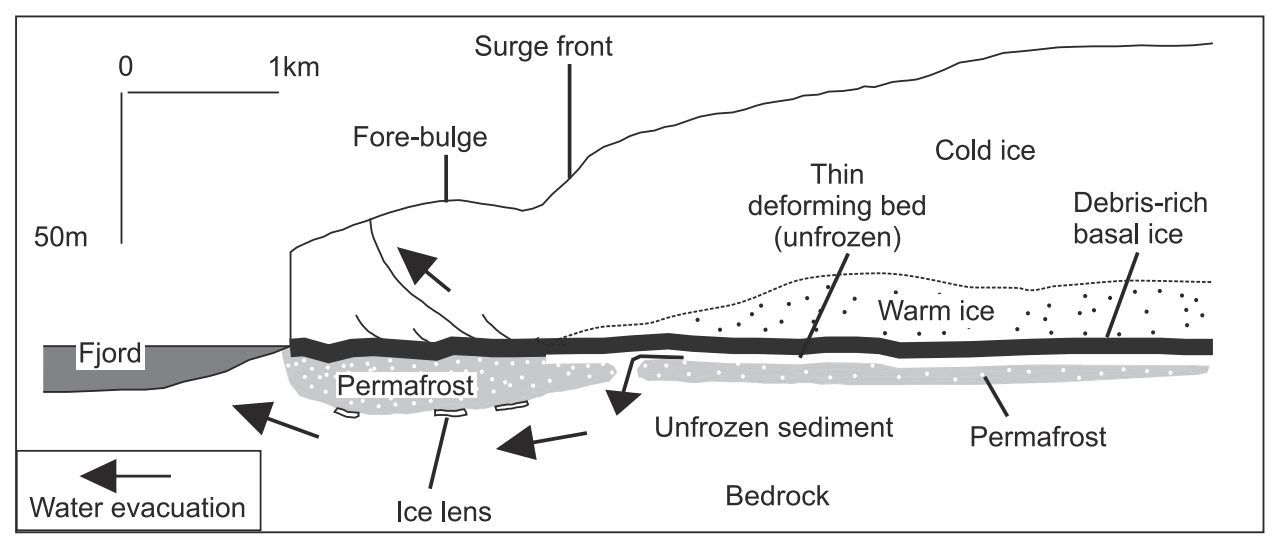

Figure 11. Conceptual model of the geometrical, thermal, and hydrological regimes of Bakaninbreen based on the seismic, GPR, and supplementary borehole data (modified from Murray et al. [2000]). Surge propagation is by sliding or the deformation of a thin layer of sediment, overlying permafrost. The permafrost forms an impermeable seal for pressurized basal water, which helps to maintain the surge. When the surge front reaches a region where the basal water can escape through the permafrost, the surge begins to terminate. Some water may also escape to the glacier surface through fractures within the ice. For completeness, some features interpreted by Murray et al. [2000] from the GPR surveys are also included, even though they were not covered by the seismic lines (e.g., the ice lenses beneath the forebulge).

glacier bed. The areas of thawed sediment that we have identified beneath the glacier may be this escape route. Progression of the surge front over this point will have coincided with a corresponding change in the conditions at the bed as the thermal boundary between a frozen interface and a thawed one (the basal thermal boundary) propagated downstream. When this boundary reached the areas of thawed sediment, the water contained in the sediment layer beneath the ice, which previously had no route of escape, could then drain through the permafrost and out of the high-pressure, subglacial system (Figure 11). If this interpretation is correct, then surge termination would be primarily controlled by the distribution of permafrost beneath the glacier before the surge began, rather than by any feature of the surge itself. The release of water when the surge front passed an area where drainage through the permafrost was possible could have initiated the end of the surge. Had no such areas existed, the surge front may have propagated all the way to the glacier terminus before the surge stopped. Conversely, had there been a region of discontinuous permafrost farther upstream, the surge may well have stopped there, rather than at its present location.

[51] This proposed mechanism for surge termination requires an impermeable layer of permafrost beneath a considerable part the glacier. In polar or subpolar regions where glaciers are often polythermal, permafrost is common and may well be extensive beneath glaciers thin enough (less than around $100-150 \mathrm{~m}$ ) for the cold winter temperatures to influence the glacier bed [Björnsson et al., 1996]. Warmer regions, where temperate glaciers dominate, are less likely to have sufficient permafrost for this termination mechanism. While other impermeable layers beneath a temperate glacier can be envisaged (e.g., hard bedrock or an impermeable sediment), we have no evidence to show they contribute to surges the way that we believe the permafrost layer does beneath Bakaninbreen. Hence, at present, we believe that our surge termination mechanism applies only to polythermal glaciers.

\subsection{Water Escape Through Fractures in the Ice}

[52] Another possible escape route for high-pressure subglacial water is through fractures within the ice [e.g., Bennett et al., 2000], and Murray et al. [1998] describe evidence for water within the ice reaching the surface of the surge front on Bakaninbreen. Hence it may be possible that escape through fractures (Figure 11) also contributed to a reduction in water pressure within the basal sediments leading to the termination of the surge. However, on the basis of the results of the seismic surveys we believe that escape through the discontinuous permafrost was the dominant factor triggering the surge termination, in this instance.

\subsection{Time Since Surge Termination}

[53] Our proposed mechanism for surge termination relies on the assumption that the conditions we observed have not changed significantly since the time of termination, despite the intervening 3-8 year period. The termination of other glacier surges has been associated with sharp changes in speed, water discharge, and water sediment concentration [e.g., Kamb et al., 1985; Echelmeyer et al., 1987; Harrison et al., 1994], implying modification of at least some of the basal characteristics. However, we believe it is likely that conditions beneath Bakaninbreen will not have changed too much over the last few years for a number of reasons.

1. Modification of the permafrost beneath Bakaninbreen is unlikely to be a rapid process as sources of heat for melting are limited and deformation is more likely within the thawed sediment layer, rather than in the deeper permafrost. Hence it is unlikely that major changes to the permafrost distribution will have occurred since the surge terminated.

2. The rapid changes seen on termination elsewhere are on temperate glaciers, in which dynamic and geometrical changes occur far quicker than in polythermal surges. 
3. The surge front on Bakaninbreen slowed down only very gradually and has seen little modification in geometry since it stopped moving [Dowdeswell et al., 1991; Murray et al., 1998]. This implies that changes at the bed were similarly slow once termination was initiated.

[54] These arguments are supported by data from instruments inserted into the bed of Bakaninbreen both upstream and downstream of the surge front, following termination. These do not indicate significant long-term changes in the basal conditions upstream of the surge front [Murray and Porter, 2001]. Hence, while we acknowledge the possibility that the basal conditions could have suffered some postsurge development, we consider it very likely that they are still a good indication of those present at the time the surge stopped.

\section{Discussion and Conclusions}

[55] We have used high-resolution seismic surveys combined with coincident ground-penetrating radar data to determine some of the glacial and subglacial structure on a polythermal, surge-type glacier. Figure 11 illustrates our conceptual model of the geometrical, thermal, and hydrological regimes of Bakaninbreen based on the seismic and radar surveys, combined with supporting borehole data. The seismic surveys were concentrated just upstream of the surge front and were carried out 3 years or more after the termination of the last surge. The main features of our interpretation are as follows:

1. Ice thickness in the region of the surveys varies between $105 \mathrm{~m}$ and $129 \mathrm{~m}$.

2. The main seismic reflection comes from either the bottom of the ice or more likely, from the bottom of a thin ( $\sim 50 \mathrm{~cm})$ layer of water-saturated, deforming sediment on which the ice rests.

3. Within the measurement errors we can detect no significant difference between the ice thicknesses from the seismic and the radar techniques. Murray et al. [2000] interpreted the main radar reflection as the top of a basal ice layer, whereas the main seismic reflection comes from the bottom of the ice, or the bottom of a thin subglacial deforming sediment layer. In the region of the seismic surveys the basal ice layer cannot be more than around $5 \mathrm{~m}$ thick and may even be absent.

4. Beneath the ice and the deforming bed layer, we have determined acoustic impedance values for the subglacial material and identified the presence of both permafrost and thawed, nondeforming sediments.

5. The permafrost varies considerably. In places, it is probably many meters thick and continuous over a wide area. Elsewhere, it is thin and discontinuous, and thawed sediment dominates. In some places, the permafrost may be absent.

6. Beneath the permafrost, thawed sediment extends down to the underlying bedrock, probably at least $15 \mathrm{~m}$ beneath the base of the glacier and possibly more over much of the region.

7. We have detected reflections from bed-parallel interfaces within the bedrock down to depths of around $100 \mathrm{~m}$ below the glacier bed.

[56] We cannot be certain to what degree the basal conditions in the region of our surveys have evolved since the termination of the surge. We assume there has been little change, as the time since the termination is relatively short and changes are expected to be slow. Hence the regions of thawed sediment may be routes through which water could escape from a high-pressure hydrological regime at the glacier base. We believe this is the mechanism by which the surge may have begun to terminate, possibly combined with escape through fractures in the ice. Termination of the surge was therefore primarily controlled by the preexisting permafrost distribution at the bed of the glacier, rather than any feature of the surge itself. At the moment, we do not know why discontinuous permafrost should have been present at this particular point, rather than elsewhere on the glacier. Further work during quiescence on Bakaninbreen, or on other glaciers prior to surging, may help to answer that question.

[57] Although controlled-source seismic techniques are not new to glaciology, we believe that the work described here demonstrates their continued applicability. It is possible to improve earlier studies, and there is potential to address further issues. Some of the possible applications we envisage include using basal conditions to indicate why some glaciers do not surge, even though other factors appear to predispose them to do so; investigating the differences between hard and soft bed glacier dynamics; mapping broad-scale subglacial hydrology from the degree of sediment saturation [e.g., Smith, 1997b]; mapping subglacial permafrost distribution; in certain favorable conditions we envisage being able to determine subglacial conditions during a surge, provided access is possible to sites where point measurements can be made; and identification of internal sediment layers and fabric changes within the ice [e.g., Bentley, 1971; Anandakrishnan et al., 1995; Smith, 1996].

[58] Limitations of the seismic technique must be kept in mind. For profiles the source must be as repeatable as possible so the layer in which the charges are placed must be fairly homogeneous. The resolution of seismic surveys will always be less than that from GPR. Recent seismic work on another glacier in Svalbard suggests that a resolution of $2 \mathrm{~m}$ is achievable in good conditions, but improving this significantly would probably require further development of alternative sources. The use of explosives may limit the application of our techniques in some situations. One example is rock glaciers, where the risk of fly rock might preclude explosives, emphasizing the requirement to consider alternative sources.

[59] Finally, we emphasize the benefits of combining seismic and GPR surveys. As a result, we have presented a technique which will allow the identification of a basal ice layer which is more than a few meters thick, and the ability to map it over wide areas. Combining these two techniques is becoming more widespread, particularly in shallow sedimentary environments [e.g., Cardimona et al., 1998; Ghose et al., 1998; Baker et al., 2001], but in sediments the GPR penetration may be limited to as little as a few meters by absorption, whereas acquiring good quality seismic data in the upper 10-20 $\mathrm{m}$ is often difficult due to source noise. Electromagnetic absorption is much less in ice (particularly cold ice) and depth penetration for GPR in a glacier can be an order of magnitude more than in sediments. Hence both seismic and GPR surveys can often target the full depth of a 
glacier and even deeper into the bed in some cases [e.g., Murray et al., 2000]. We believe that complementary seismic and GPR surveys have the potential to elucidate considerable glacial and subglacial information in the future.

[60] Acknowledgments. This research was funded by NERC (GR3/ R9757). Nick Cox (NERC Arctic Research Station) and Jon Guldahl (Norsk Polarinstitutt) helped with planning and logistics. Sophie Sándor helped to process the GPR data. Reviews by Jeffrey Kavanaugh and the Associate Editor helped to improve the manuscript.

\section{References}

Anandakrishnan, S., A. M. Smith, S. Saustrup, V. Sen, I. W. D. Dalziel, P. L. Stoffa, and D. D. Blankenship, Antalith-Seismic reflection profile in West Antarctica, Antarct. J. U. S., 30, 20-21, 1995.

Atre, S. R., and C. R. Bentley, Laterally varying basal conditions beneath ice streams B and C, West Antarctica, J. Glaciol., 39, 507-514, 1993.

Baker, G. S., D. W. Steeples, C. Schmeissner, M. Pavlovic, and R. Plumb, Near-surface imaging using coincident seismic and GPR data, Geophys. Res. Lett., 28, 627-630, 2001

Barrett, P. J., and P. C. Froggatt, Densities, porosities and seismic velocities of some rocks from Victoria Land, Antarctica, N. Z. J. Geol. Geophys. 21, 175-187, 1978

Bennett, M. R., D. Huddart, and R. I. Waller, Glaciofluvial crevasse and conduit fills as indicators of supraglacial dewatering during a surge, Skeiðarárjökull, Iceland, J. Glaciol., 46, 25-34, 2000.

Bentley, C. R., Seismic evidence for moraine within the basal Antarctic ice sheet, in Antarctic Snow and Ice Studies II, Antarct. Res. Ser., vol. 16 , edited by A. P. Crary, pp. 89-129, AGU, Washington, D. C., 1971.

Björnsson, H., Hydrological characteristics of the drainage system beneath a surging glacier, Nature, 395, 771-774, 1998

Björnsson, H., Y. Gjessing, S.-E. Hamran, J. O. Hagen, O. Liestøl, F Pálsson, and B. Erlingsson, The thermal regime of sub-polar glaciers mapped by multi-frequency radio-echo sounding, J. Glaciol., 42, 23 32, 1996.

Blake, E., G. K. C. Clarke, and M. C. Gérin, Tools for examining subglacial bed deformation, J. Glaciol., 38, 388-396, 1992.

Blankenship, D. D., C. R. Bentley, S. T. Rooney, and R. B. Alley, Seismic measurements reveal a saturated porous layer beneath an active Antarctic ice stream, Nature, 322, 54-57, 1986.

Cardimona, S. J., W. P. Clement, and K. Kadinsky-Cade, Seismic reflection and ground-penetrating radar imaging of a shallow aquifer, Geophysics, 63, 1310-1317, 1998 .

Carmichael, R. S., CRC Handbook of Physical Properties of Rocks, CRC Press, Boca Raton, Fla., 1982.

Clarke, G. K. C., Fast glacier flow: Ice streams, surging and tidewater glaciers, J. Geophys, Res., 92, 8835-8841, 1987.

Clarke, G. K. C., and E. W. Blake, Geometric evolution of a surge-type glacier in its quiescent state: Trapridge Glacier, Yukon Territory, Canada, 1969-89, J. Glaciol., 37, 158-169, 1991.

Clarke, G. K. C., S. G. Collins, and D. E. Thompson, Flow, thermal structure and subglacial conditions of a surge-type glacier, Can. J. Earth. Sci., $21,232-240,1984$

Dallmann, W. K., A. Andersen, S. G. Bergh, H. D. Maher, and Y. Ohta Tertiary fold-and-thrust belt of Spitsbergen, Svalbard, Nor. Polarinst Medd., 128, 46 pp., 1993.

Dowdeswell, J. A., G. S. Hamilton, and J. O. Hagen, The duration of active phases on surge-type glaciers: Contrasts between Svalbard and other regions, J. Glaciol., 37, 338-400, 1991.

Drewry, D. J., Radar and seismic ice-thickness measurements compared on sub-polar glaciers in Svalbard, Ann. Glaciol., 9, 246, 1987.

Dvorkin, J., M. Prasad, A. Sakai, and D. Lavoie, Elasticity of marine sediments: Rock physics modelling, Geophys. Res. Lett., 26, $1781-$ 1784, 1999

Echelmeyer, K., and W. Zhongxiang, Direct observation of basal sliding and deformation of basal drift at sub-freezing temperatures, J. Glaciol., 33, 83-98, 1987

Echelmeyer, K., R. Butterfield, and D. Cuillard, Some observations on a recent surge of Peters Glacier, Alaska, U.S.A., J. Glaciol., 115, 341-345, 1987.

Eiken, O., Aspects of the seismic method, in Seismic Atlas of Western Svalbard, edited by O. Eiken, Nor. Polarinst., Medd., 130, 59-63, 1994.

Fischer, U. H., and G. K. C. Clarke, Ploughing of subglacial sediment, $J$. Glaciol., 40, 97-106, 1994.

Fuller, S., and T. Murray, Evidence against pervasive bed deformation during the surge of an Icelandic glacier, in Deformation of Glacial Ma- terials, edited by A. J. Maltman, B. Hubbard, and M. J. Hambrey, Geol. Soc. Spec. Publ., 176, 203-216, 2000

Gardner, G. H. F., L. W. Gardner, and A. R. Gregory, Formation velocity and density-The diagnostic basics for stratigraphic traps, Geophysics, 39, 770-780, 1974

Ghose, R., V. Nijhof, J. Brouwer, Y. Matsubara, Y. Kaida, and T. Takahashi, Shallow to very shallow, high-resolution reflection seismic using a portable vibrator system, Geophysics, 63, 1295-1309, 1998.

Gow, A. J., and D. A. Meese, Nature of basal debris in the GISP2 and Byrd ice cores and its relevance to bed processes, Ann. Glaciol., 22, 134-140, 1996.

Hambrey, M. J., J. A. Dowdeswell, T. Murray, and P. R. Porter, Thrusting and debris-entrainment in a surge-type glacier, Ann. Glaciol., 22, $241-$ 248, 1996

Hamilton, E. L., Sound velocity and related properties of marine sediments, North Pacific, J. Geophys. Res., 75, 4423-4446, 1970.

Harrison, W. D., K. A. Echelmeyer, E. F. Chacho, C. F. Raymond, and R. J. Benedict, The 1987-88 surge of West Fork Glacier, Susitna Basin, Alaska, U.S.A., J. Glaciol., 135, 241-254, 1994.

Hart, J. K., and R. I. Waller, An investigation of the debris-rich basal ice from Worthington Glacier, Alaska, USA, J. Glaciol., 45, 54-62, 1999.

Herrod, L. D. B., Sea-bottom topography beneath Ronne Ice Shelf, Antarctica, in Filchner-Ronne Ice Shelf Programme Report No. 7, edited by H. Kohnen, pp. 72-80, Alfred-Wegener Inst. for Polar and Mar. Res., Bremerhaven, Germany, 1986.

Hubbard, B., and M. Sharp, Basal facies and their formation in the Western Alps, Arct. Alp. Res., 27, 301-310, 1995.

Jarvis, E. P., and E. C. King, The seismic wavefield recorded on an Antarctic ice shelf, J. Seismic Explor., 2, 69-86, 1993.

Kamb, B., Glacier surge mechanisms based on a linked cavity configuration of the basal water conduit system, J. Geophys. Res., 92, 9083-9100, 1987.

Kamb, B., C. F. Raymond, W. D. Harrison, H. Engelhardt, K. A. Echelmeyer, N. Humphrey, M. M. Brugman, and T. Pfeffer, Glacier surge mechanism: 1982-1983 surge of Variegated Glacier, Alaska, Science, 227, 469-479, 1985

Kohnen, H., The temperature dependence of seismic waves in ice, J. Glaciol., 13, 144-147, 1974

Kurfurst, P. J., Ultrasonic wave measurements on frozen soils at permafrost temperatures, Can. J. Earth Sci., 13, 1571, 1976.

Kuster, G. T., and M. N. Toksöz, Velocity and attenuation of seismic waves in two-phase media, part 1, Theoretical formulations, Geophysics, 39, $587-606,1974$

Lawson, D. E., Sedimentological analysis of the western terminus region of the Matanuska Glacier, Alaska, CRREL Rep. 79-9, Cold Reg. Res. and Eng. Lab., Hanover, N. H., 1979.

Lawson, D. E., J. C. Strasser, E. B. Evenson, R. B. Alley, G. J. Larson, and S. A. Arcone, Glaciohydraulic supercooling: A freeze-on mechanism to create stratified, debris-rich basal ice, I, Field evidence, J. Glaciol., 44, 547-562, 1998

Mavko, G., T. Mukerji, and J. Dvorkin, The Rock Physics Handbook, Cambridge Univ. Press, New York, 1998.

Meier, M. F., and A. Post, What are glacier surges?, Can. J. Earth. Sci., 6 , $807-817,1969$

Morgan, N. A., Physical properties of marine sediments as related to seismic velocities, Geophysics, 34, 529-545, 1969.

Murray, T., and P. R. Porter, Basal conditions beneath a soft-bedded ploythermal surge-type glacier: Bakaninbree, Svalbard, Quat. Int., 86 , $103-116,2001$

Murray, T., D. L. Gooch, and G. W. Stuart, Structures within the surge front at Bakaninbreen using ground penetrating radar, Ann. Glaciol., 24, $122-$ $129,1997$.

Murray, T., J. A. Dowdeswell, D. J. Drewry, and I. Frearson, Geometric evolution and ice dynamics during a surge of Bakaninbreen, Svalbard, $J$. Glaciol., 44, 263-272, 1998.

Murray, T., G. W. Stuart, P. J. Millar, J. Woodward, A. M. Smith, P. R. Porter, and H. Jiskoot, Glacier surge propagation by thermal evolution at the bed, J. Geophys. Res., 105, 13,491-13,507, 2000.

Nafe, J. E., and C. L. Drake, Physical properties of marine sediments, in The Sea, vol. 3, edited by M. N. Hill, pp. 794-815, Wiley-Interscience, New York, 1963.

Nolan, M., and K. Echelmeyer, Seismic detection of transient changes beneath Black Rapids Glacier, Alaska, U.S.A., I, Techniques and observations, J Glaciol., 149, 119-131, 1999.

Ødegard, R. S., J. O. Hagen, and S.-E. Hamran, Comparison of radio-echo sounding $(30-1000 \mathrm{MHz})$ and high-resolution borehole temperature measurements at Finsterwalderbreen, southern Spitsbergen, Svalbard, Ann. Glaciol., 24, 262-267, 1997.

Porter, P. R., Glacier surging: Subglacial sediment deformation and ice-bed coupling, Ph.D. thesis, 235 pp., Univ. of Leeds, Leeds, England, 1997. 
Porter, P. R., T. Murray, and J. A. Dowdeswell, Sediment deformation and basal dynamics beneath a glacier surge front: Bakaninbreen, Svalbard, Ann. Glaciol., 24, 21-26, 1997.

Punning, J.-M., L. Troitskiy, and R. Rajamae, The genesis and age of Quaternary deposits in the eastern part of Van Mijenfjord, west Spitsbergen, Geol. Foeren. Stockholm Foerh., 98(567), part 4, 343-347, 1976.

Richards, M. A., Seismic evidence for a weak basal layer during the 1982 surge of Variegated Glacier, Alska, U.S.A., J. Glaciol, 116, 111-120, 1988.

Robin, G. deQ., Glaciology III, Seismic shooting and related investigations, Norw. Br. Swed. Antarct. Exped., 1949-51, 5, Nor. Polarinst., Oslo, Norway.

Röthlisberger, H., Seismic exploration in cold regions, CRREL Monogr. IIA2a, Cold Reg. Res. and Eng. Lab., Hanover, N. H., 1972.

Salvigsen, O., and T. S. Wisnes, Braganzavægen, Geological map of Svalbard, scale 1:100,000, sheet C10G, Nor. Polarinst., Oslo, 1989.

Sharp, M., J. Jouzel, B. Hubbard, and W. Lawson, The character, structure and origin of the basal ice layer of a surge-type glacier, J. Glaciol., 40, 327-340, 1994.

Smith, A. M., Ice shelf basal melting at the grounding line, measured from seismic observations, J. Geophys. Res., 101, 22,749-22,755, 1996.

Smith, A. M., Basal conditions on Rutford Ice Stream, West Antarctica, from seismic observations, J. Geophys. Res., 102, 543-552, 1997a.

Smith, A. M., Variations in basal conditions on Rutford Ice Stream, West Antarctica, J. Glaciol., 43, 245-255, 1997b.

Smith, A. M., Basal conditions on Rutford Ice Stream and Carlson Inlet: Implications for ice stream flow, in Filchner-Ronne Ice Shelf Report No.
13, edited by H. Oerter, Alfred-Wegener Inst. for Polar and Mar. Res., Bremerhaven, Germany, 2000.

Sugden, D. E., C. M. Clapperton, J. C. Gemmell, and P. G. Knight, Stable isotopes and debris in basal glacier ice, South Georgia, Southern Ocean, J. Glaciol., 33, 325-329, 1987.

Zimmerman, R. W., and M. S. King, The effect of the extent of freezing on seismic velocities in unconsolidated permafrost, Geophysics, 51, 1285$1290,1986$.

A. F. Clough, School of Earth Sciences, University of Leeds, Leeds LS2 9JT, UK.

B. M. Davison, Institute of Environmental and Biological Sciences, Lancaster University, Lancaster LA1 4YQ, UK. (davisonb@exchange. lancs.ac.uk)

H. Jiskoot, Department of Geography, University of Calgary, 2500 University Drive NW, Calgary, Alberta, Canada T2N 1N4. (jiskoot@ ucalgary.ca)

T. Murray, School of Geography, University of Leeds, Leeds LS2 9JT, UK. (tavi@geog.leeds.ac.uk)

A. M. Smith, Physical Sciences Division, British Antarctic Survey, Natural Environmental Research Council, High Cross, Madingley Road, Cambridge CB3 0ET, UK. (amsm@bas.ac.uk)

J. Woodward, Department of Geography and Earth Sciences, Brunel University, Uxbridge UB8 3PH, UK. (John.Woodward@brunel.ac.uk) 